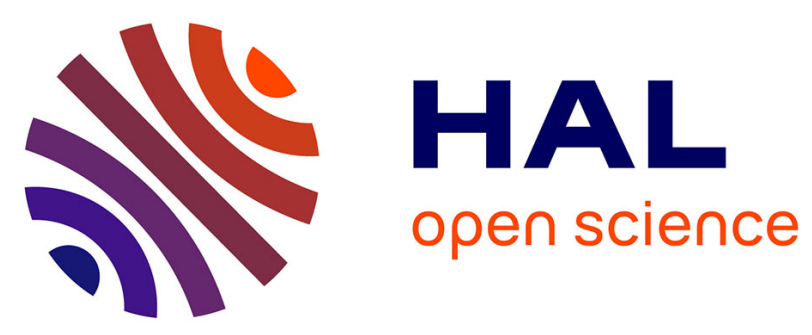

\title{
A Quantitative Tomotectonic Plate Reconstruction of Western North America and the Eastern Pacific Basin
}

Edward Clennett, Karin Sigloch, Mitchell Mihalynuk, Maria Seton, Martha Henderson, Kasra Hosseini, Afsaneh Mohammadzaheri, Stephen Johnston, R. Dietmar Müller

\section{To cite this version:}

Edward Clennett, Karin Sigloch, Mitchell Mihalynuk, Maria Seton, Martha Henderson, et al.. A Quantitative Tomotectonic Plate Reconstruction of Western North America and the Eastern Pacific Basin. Geochemistry, Geophysics, Geosystems, 2020, 21 (8), 10.1029/2020GC009117 . hal-03425540

\author{
HAL Id: hal-03425540 \\ https://hal.science/hal-03425540
}

Submitted on 23 Nov 2021

HAL is a multi-disciplinary open access archive for the deposit and dissemination of scientific research documents, whether they are published or not. The documents may come from teaching and research institutions in France or abroad, or from public or private research centers.
L'archive ouverte pluridisciplinaire HAL, est destinée au dépôt et à la diffusion de documents scientifiques de niveau recherche, publiés ou non, émanant des établissements d'enseignement et de recherche français ou étrangers, des laboratoires publics ou privés. 


\section{Geochemistry, Geophysics, Geosystems}

\author{
RESEARCH ARTICLE \\ 10.1029/2020GC009117 \\ Key Points: \\ - We present a plate reconstruction \\ model for western North America \\ and the eastern Pacific for the past \\ $170 \mathrm{Myr}$ \\ - The plate model uses "tomotectonic \\ analysis"- a synthesis of mantle and \\ geological evidence \\ - Detailed terrane motions show the \\ assembly of the North American \\ Cordillera from an intraoceanic arc \\ setting
}

Supporting Information:

- Supporting Information S1

- Data Set S1

- Data Set S2

- Movie S1

- Movie S2

Correspondence to:

E. J. Clennett,

edward.clennett@earth.ox.ac.uk

\section{Citation:}

Clennett, E. J., Sigloch, K., Mihalynuk, M. G., Seton, M., Henderson, M. A., Hosseini, K., et al. (2020). A

quantitative tomotectonic plate reconstruction of western North America and the eastern Pacific basin. Geochemistry, Geophysics, Geosystems, 20, e2020GC009117. https://doi.org/ 10.1029/2020GC009117

Received 20 APR 2020 Accepted 23 JUN 2020 Accepted article online 24 JUN 2020

(C)2020. The Authors.

This is an open access article under the terms of the Creative Commons Attribution License, which permits use, distribution and reproduction in any medium, provided the original work is properly cited.

\section{A Quantitative Tomotectonic Plate Reconstruction of Western North America and the Eastern Pacific Basin}

\author{
Edward J. Clennett ${ }^{1}$ iD, Karin Sigloch ${ }^{1}$ iD, Mitchell G. Mihalynuk ${ }^{2}$ iD, Maria Seton ${ }^{3}$ iD, \\ Martha A. Henderson ${ }^{2}$, Kasra Hosseini ${ }^{1,4}$ iD, Afsaneh Mohammadzaheri ${ }^{1}$ iD, \\ Stephen T. Johnston ${ }^{5}$ iD, and R. Dietmar Müller ${ }^{3}$ iD \\ ${ }^{1}$ Department of Earth Sciences, University of Oxford, Oxford, UK, ${ }^{2}$ British Columbia Geological Survey, Victoria, British \\ Columbia, Canada, ${ }^{3}$ EarthByte Group, School of Geosciences, The University of Sydney, Sydney, New South Wales, \\ Australia, ${ }^{4}$ The Alan Turing Institute, London, UK, ${ }^{5}$ Department of Earth and Atmospheric Sciences, University of \\ Alberta, Edmonton, Alberta, Canada
}

\begin{abstract}
Plate reconstructions since the breakup of Pangaea are mostly based on the preserved spreading history of ocean basins, within absolute reference frames that are constrained by a combination of age-progressive hotspot tracks and paleomagnetic data. The evolution of destructive plate margins is difficult to constrain from surface observations as much of the evidence has been subducted. Seismic tomography can directly constrain paleotrench locations by imaging subducted lithosphere in the mantle. This new evidence, combined with the geological surface record of subduction, suggests that several intraoceanic arcs existed between the Farallon Ocean and North America during late Mesozoic times-in contrast to existing quantitative models that typically show long-lived subduction of the Farallon plate beneath the continental margin. We present a continuously closing plate model for the eastern Pacific basin from $170 \mathrm{Ma}$ to present, constrained using "tomotectonic analysis" - the integration of surface and subsurface data. During the Middle to Late Jurassic, we show simultaneous eastward and westward subduction of oceanic plates under an archipelago composed of Cordilleran arc terranes. As North America drifts westward, it diachronously overrides the archipelago and its arcs, beginning in the latest Jurassic. During and postaccretion, Cordilleran terranes are translated thousands of kilometers along the continental margin, as constrained by paleomagnetic evidence. Final accretions to North America occur during the Eocene, ending 100 Myr of archipelago override. This model provides a detailed, quantitative tectonic history for the eastern Pacific domain, paving the way for tomotectonic analysis to be used in other paleo-oceanic regions.
\end{abstract}

Plain Language Summary Tectonic plate reconstructions back to the Jurassic period are mostly based on data from preserved ocean crust. However, many oceanic plates have been lost into the Earth's interior by subduction, making their reconstruction a challenge. We combine seismic images of the deep mantle with geological data to locate the vanished plates in the Earth's mantle and restore them to their previous positions at the surface. The trenches where the plates subducted can be paired with extinct arc volcanoes in western North America. Jointly, these lines of evidence suggest that the eastern Pacific basin was broken up into several smaller plates-in contrast to the long-held view that one or two large plates subducted eastward beneath the west coast of North America for the last 170 Myr. Instead, we model simultaneous eastward and westward subduction of plates under a vast archipelago of volcanic arcs that sat stationary in the northeastern proto-Pacific. North America was pulled westward into this archipelago and gradually collided with its microcontinents, which today form the North American Cordillera. Our model provides a more detailed and complete tectonic history for the eastern Pacific and highlights how our method can be used to reconstruct vanished oceans.

\section{Introduction}

Quantitative plate reconstructions traditionally rely on the interpretation of seafloor spreading isochrons and the locations and orientations of fracture zones recorded on ocean basins, coupled with age-progressive hotspot tracks and paleomagnetic data from continents (e.g., Müller et al., 2019; Seton et al., 2012). Although the Earth's "Pangaean hemisphere" is relatively well constrained by seafloor spreading records, this is at the expense of the "Panthalassan hemisphere," much of which has been removed from the surface by subduction. Figure 1 illustrates the evolution of thinking on reconstructing the eastern Pacific 

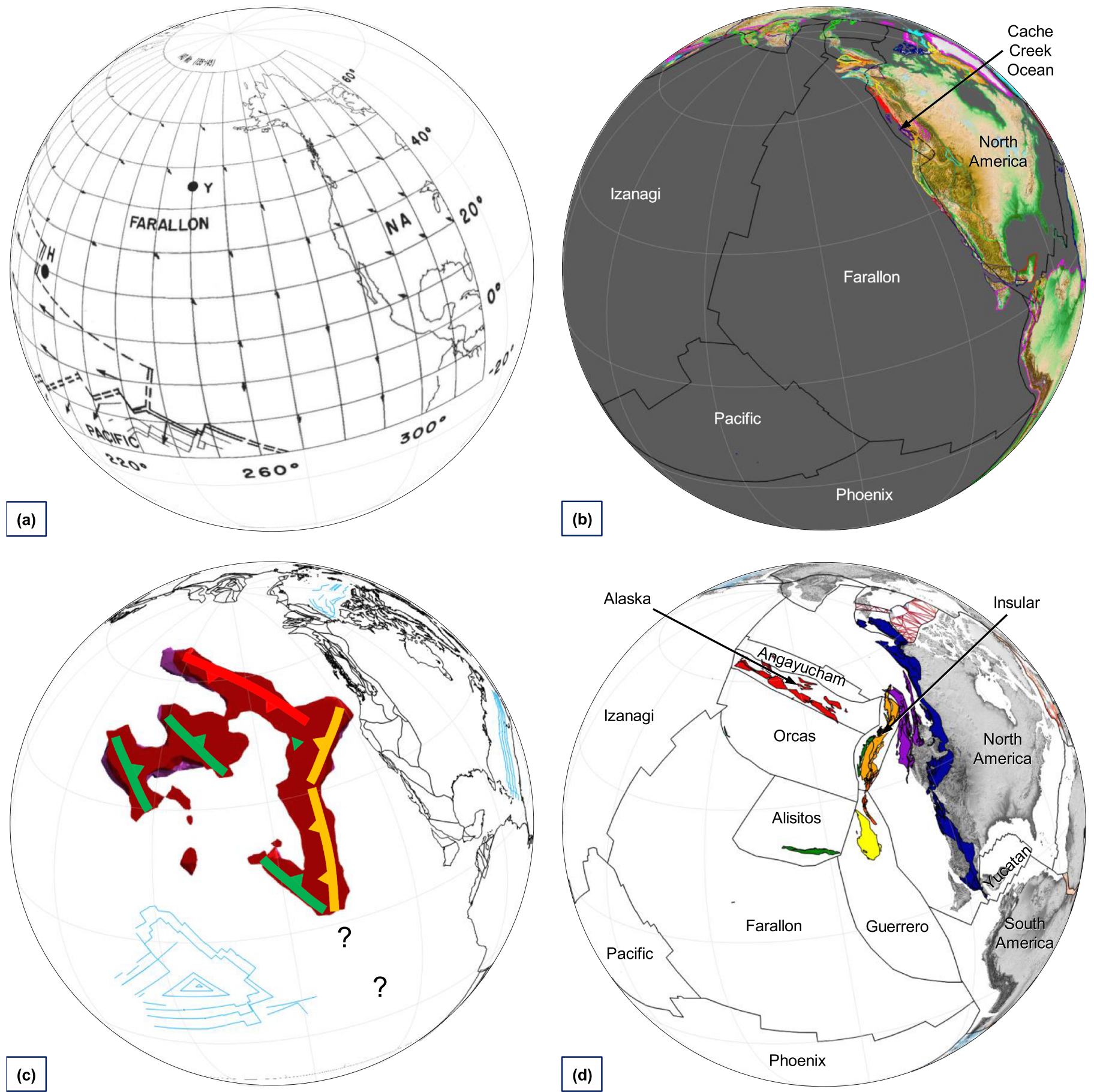

Figure 1. Four alternative studies on the tectonics of the eastern Pacific basin, all shown at $140 \mathrm{Ma}$, which illustrate the changing ideas for the tectonic history of the eastern Pacific basin. (a) Simple division of northeast Panthalassa into three large oceanic plates, with long-lived "Andean-style" subduction underneath the North American continent (Engebretson et al., 1985). This was presented as tables of Euler poles and snapshots of the plate configuration. (b) Closed global plate model of Shephard et al. (2013), with continuously evolving boundaries. (c) Intraoceanic arc model of Sigloch and Mihalynuk (2017), but only showing trenches, not closed plates. (d) Continuously closing plate model in this study, documenting the evolution of a "Cordilleran" archipelago that existed offshore western North America during Jurassic and Cretaceous times and has since accreted to the continent.

basin as part of Panthalassa. Extrapolating from conjugate isochrons and fracture zones on the Pacific plate, Engebretson et al. (1985) presented a quantitative plate model for the last $180 \mathrm{Myr}$ where Panthalassa was divided into the Pacific, Izanagi, Farallon, Phoenix, and Kula oceanic plates (Figure 1a). They proposed 


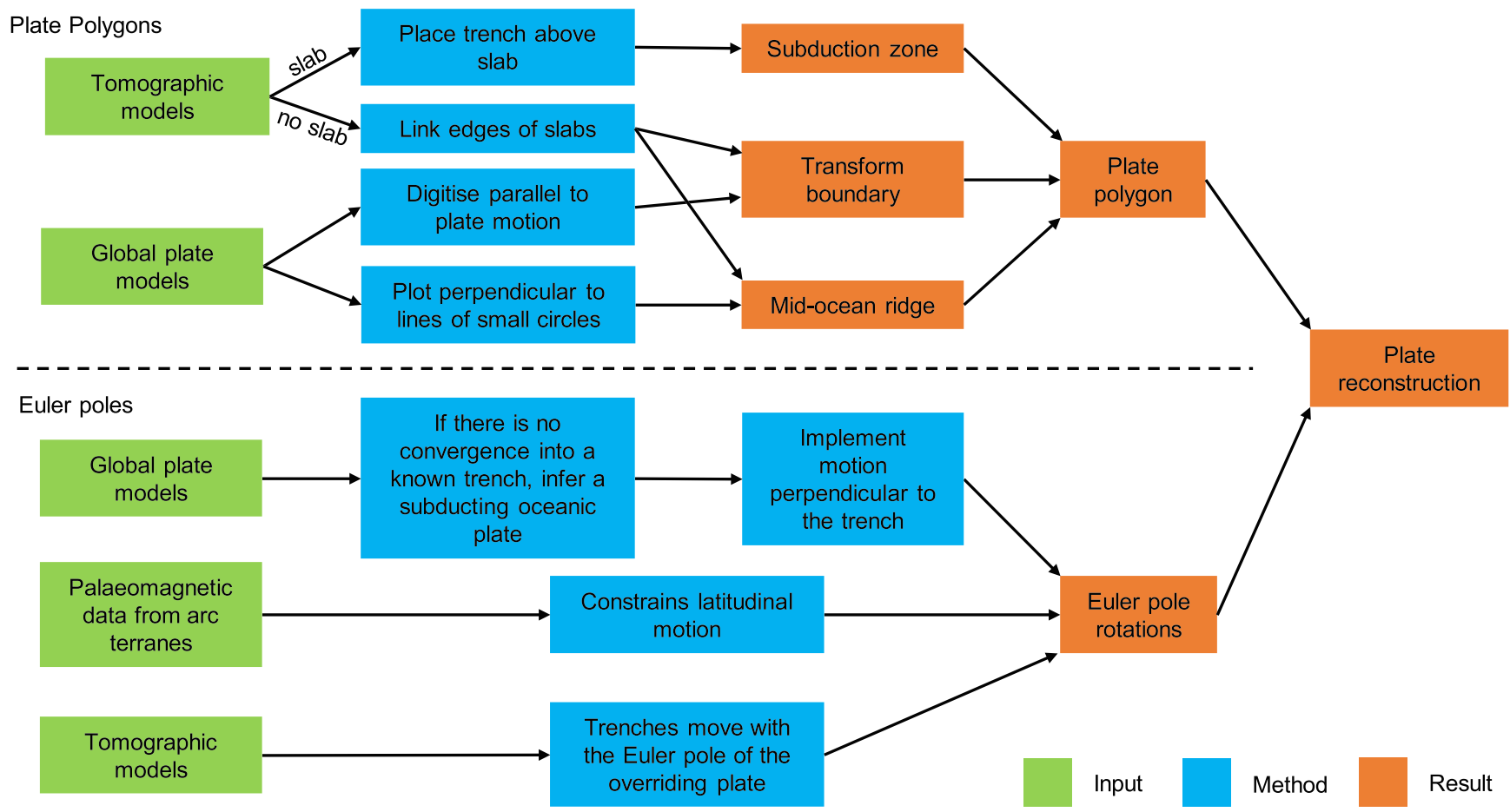

Figure 2. Diagram showing the decision-making process applied in tomotectonic plate reconstructions.

continuous, "Andean-type" subduction of the Farallon plate under the entire length of the North American continental margin, while explicitly noting that this choice was based on land geological interpretations. Persistent Farallon-beneath-continent subduction has been inherited by most modern reconstructions of this region (e.g., Müller et al., 2019; Seton et al., 2012; Shephard et al., 2013) (Figure 1b).

This paleogeography has been challenged on geological grounds and more recently by tomographically imaged distributions of subducted seafloor. Geological evidence along the length of the western margin of North America (Dickinson, 2004, 2008; Ingersoll, 2008; Ingersoll \& Schweickert, 1986; Moores, 1970, 1998) suggests that the northeastern Pacific basin was instead characterized by intraoceanic subduction, analogous to the present-day southwest Pacific. Jurassic-Cretaceous arc assemblages, accretionary complexes, and ophiolites comprise large tracts of the North American Cordillera (Coney et al., 1980; Silberling et al., 1992). The differing histories of these terranes, as revealed by lithological, paleomagnetic, and fossil fauna data (e.g., Dickinson, 2008), challenge the hypothesis of “Andean-type" subduction of a single, large Farallon plate.

Driven by the geometries of subducted lithosphere ("slabs") in the mantle, combined with surface observations-a method termed "tomotectonic analysis"-Sigloch and Mihalynuk (2013, 2017) provided an archipelago-style reconstruction history of the northeastern Pacific, with trenches evolving from $200 \mathrm{Ma}$ to present (Figure 1c). However, their study did not present continuously closed rigid plates but rather discrete snapshots of subduction zone locations. This study presents the first plate model with continuously closing boundaries of the Late Jurassic-Cretaceous eastern Pacific intraoceanic arc system (Figure 1d).

\section{Methods and Data}

We used the plate reconstruction software GPlates (www.gplates.org; Müller et al., 2018) to produce a model of Pacific plate motions for the past 170 Myr. Our reconstruction has continuously closing plate polygons and is integrated within two alternative global models: Shephard et al. (2013) and Müller et al. (2019). We explore these alternative and competing models in order to show that our inferences of intraoceanic subduction are robust with respect to the choice of absolute reference frame, which introduces the largest positioning uncertainties. Shephard et al. (2013) is built into the hybrid reference frame of Seton et al. (2012), which adopts the moving hotspot frame of O'Neill et al. (2005) combined with a true polar wander corrected 


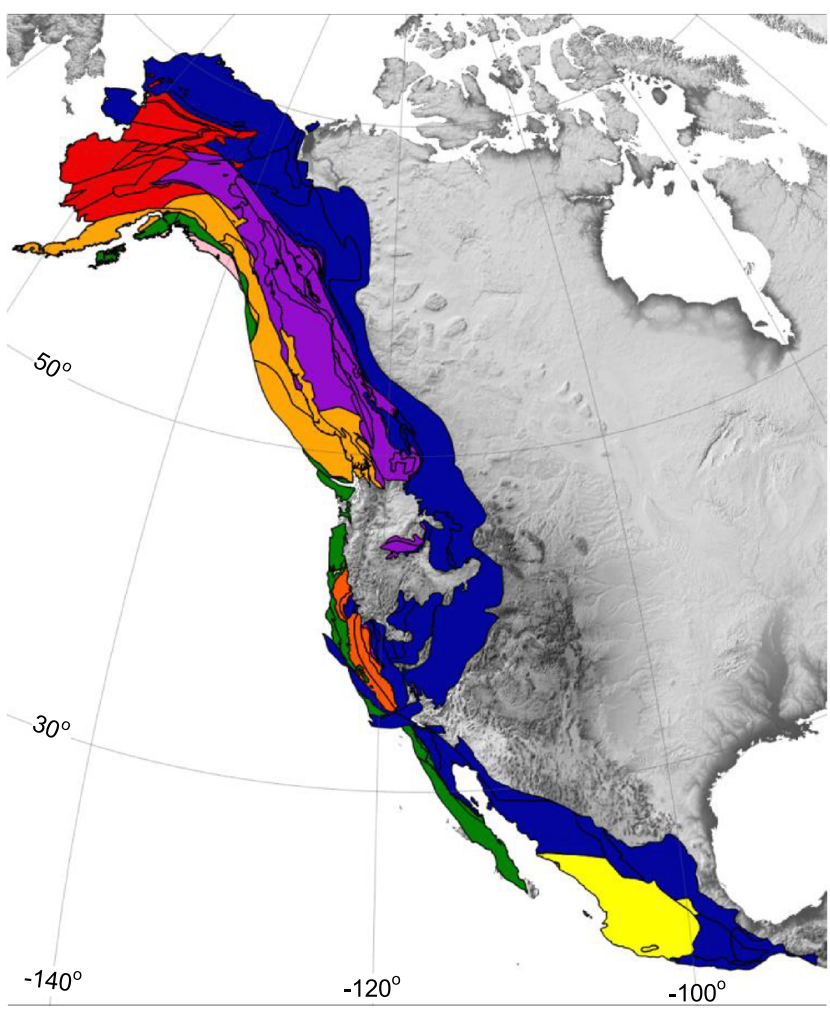

Figure 3. Terrane and superterrane affiliations used in this study: Angayucham (red), Insular (orange), Intermontane (purple), Guerrero (yellow), Western Jurassic belt (dark orange)-which is composed of the Western Klamaths, basement of the Great Valley, and northwest Sierra Nevada—North America (dark blue), Farallon (green), and Kula (pink). paleomagnetic frame for earlier times (Steinberger \& Torsvik, 2008). In contrast, Müller et al. (2019) use an optimized reference frame that minimizes trench migration and net rotation (Tetley et al., 2019). A detailed description of how the reference frames are constructed, along with an assessment of our model in light of other reference frames, can be found in the Supporting Information. This includes the "subduction reference frame" of van der Meer et al. (2010), which is not compatible with our investigation because it enforces Andean-style Farallon subduction a priori.

\subsection{Tomotectonic Analysis}

Figure 2 illustrates our workflow. First, subduction zone boundaries were implemented. As tomographically imaged slabs are proxies for the past location of trenches (Sigloch \& Mihalynuk, 2013), we placed a trench above every slab during the times when this slab is inferred to have subducted (see section 2.3). In areas where no slabs were imaged, plates were closed with transform boundaries or spreading ridges. If there was plate motion parallel to gaps between subduction zones, then plates were closed with transform boundaries. Where plates were diverging, spreading ridges were implemented. Due to the loss of seafloor magnetic lineations, the geometry and absolute positions of mid-ocean ridges were largely unconstrained. However, ridge-transform plate boundaries lie perpendicular and parallel to small circles about a pole of rotation (McKenzie \& Parker, 1967; Morgan, 1968); thus, proposed mid-ocean ridges can be digitized such that their orientations are consistent with the global plate circuit.

Digitizing trenches and closing polygons with ridge and transform boundaries necessitate hypothesizing several new plates between the Farallon plate and the North American plate, and all require stage pole rotations. As subduction zones migrate with the overriding plate (Gurnis et al., 2012), Euler rotations for these plates could be constrained using tomographic models by ensuring that subduction zones that define the plate boundary remain above imaged slabs. Paleomagnetic studies from accreted terranes were used as an additional constraint on plate motions. Some modeled oceanic plates have been entirely subducted, removing any evidence from which stage pole rotations could be determined. In these cases, we assume that plate motion was directed perpendicular to the subduction zone. This fulfills the requirement of convergence at trench boundaries and is also consistent with the observation that slab pull is the major driving force of the present-day plate circuit (Forsyth \& Uyeda, 1975).

\subsection{Terrane Model}

In addition to digitizing new plates, we developed a terrane model for the North American Cordillera. Rotations were assigned to 68 terranes, further divided into 109 subterranes to accommodate for changes in shape and size over geologic time. The Alaskan and Canadian terranes were modified after Colpron and Nelson (2011), whereas the western U.S. and Mexican terranes were based on the geometries in Dickinson (2008) and Silberling et al. (1992). Three additional terranes were adapted from other sources: Alisitos (Johnson et al., 1999), Kronotsky, and Olutorsky terranes (Domeier et al., 2017). Terranes were further grouped into four superterranes-Angayucham, Insular, Intermontane, and Guerrero-in order to facilitate tectonic interpretation on a larger scale. Remaining terranes were affiliated with the North American, Farallon, or Kula plates, based on their inferred genesis (Figure 3).

\subsection{Tomographic Models}

The primary tomographic constraints that we used for the reconstruction were the geometries of subducted lithosphere in the Sigloch_NAm_2011 regional model for North America (Sigloch, 2011) and the DETOX-P1 (Hosseini et al., 2020; Mohammadzaheri, 2019) and DETOX-P3 (Hosseini et al., 2020) global-scale models. 

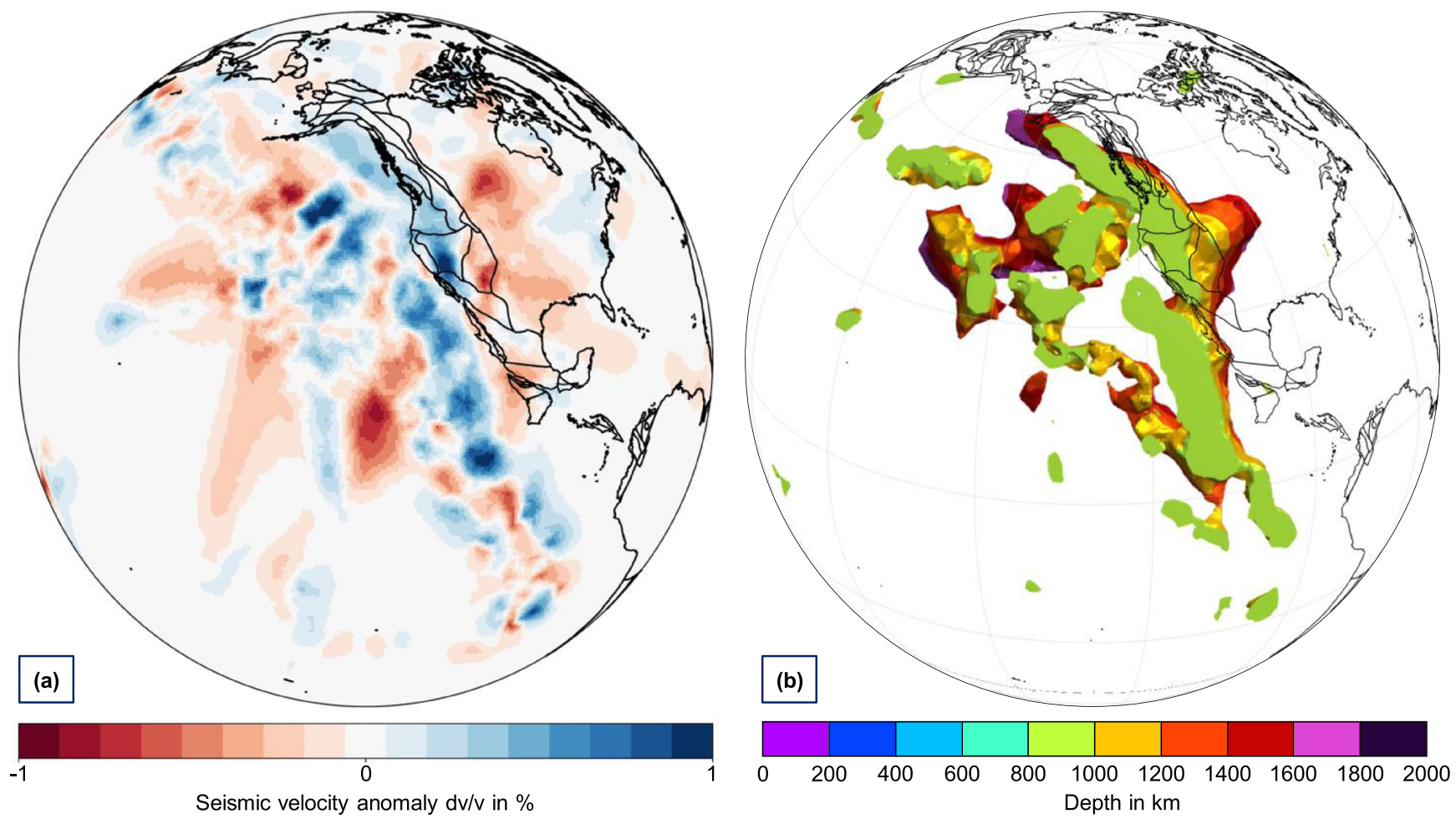

Figure 4. (a) A singular tomographic slice at 900-km depth showing regions of anomalously fast (blue) and slow (red) seismic velocity anomalies (Sigloch, 2011). Below lithospheric depths, fast anomalies are interpreted as subducted slabs of former ocean lithosphere. Slow anomalies, usually associated with mantle upwelling, were not interpreted in this study. Tomography models were rendered using SubMachine (Hosseini et al., 2018). (b) A 3D isosurface rendering of all fast anomalies $\left(d V_{p} / V_{p}>+0.2 \%\right)$ at and below 900-km depth (Sigloch, 2011). Each depth is color coded, changing every $200 \mathrm{~km}$. The position of North America at $90 \mathrm{Ma}$, which corresponds to a $10 \mathrm{~mm} /$ year sinking rate, is overlain in black. This superposition of surface and subsurface structure corresponds to a sinking rate of $10 \mathrm{~mm} /$ year, or $900 \mathrm{~km}$ in $90 \mathrm{Myr}$. The light green, linear surfaces thus map out trenches (lines of slab deposition) that were active at $90 \mathrm{Ma}$. North America is seen to be overriding two long, NNW-striking trench lines at this time, but not yet a set of more fragmented, westerly trenches. Yellow slab would have subducted between 100-120 Ma, orange slab would have subducted between 120-140 Ma, and so on.

Sigloch_NAm_2011 is a regional $P$ wave tomography model for North America. Unlike global models, which feature significant smoothing over areas with low station coverage, the region covered by Sigloch_Nam_2011 had a high density of stations as part of the USArray experiment. As a result, the linear slabs resolved are more representative of present-day trenches, and so, we favor this model over global models as the basis for interpretation of structures underneath North America. However, the Sigloch_NAm_2011 model only incorporates data up until 2008 and did not systematically include all seismic stations outside the conterminous United States. Hence, this model has lower resolution, and thus higher uncertainty, at the edges of the area of interest, particularly underneath Mexico and Alaska. Therefore, we used the DETOX-P1 and DETOX-P3 global $P$ wave models as the primary data sets for constraining slabs beneath regions away from present-day United States. DETOX-P3 includes not just P and PP data but also core-diffracted $P$ waves (Hosseini \& Sigloch, 2015), which results in more complete illumination of the lower mantle. Hence, we rely on the DETOX-P3 model when constraining the shapes and locations of the deepest slabs, which constrain our model's earliest plate boundaries.

To link the depth of a slab to the time that it would have been at the Earth's surface, we assume that slabs located at the same depth entered the mantle at the same time. Specifically, we assume that slabs located in the lower mantle sank through the mantle at an average rate of $10 \mathrm{~mm} / \mathrm{year}$, or $10 \mathrm{~km}$ in a million years. This implements the mean value of the $10 \pm 2 \mathrm{~mm} /$ year rate determined by Sigloch and Mihalynuk (2013). Their estimate quantifies the observation that the farther east a segment of the massive slab walls of Figure $4 \mathrm{~b}$ is located, the deeper the level at which it truncates upward. Upward truncation records the 
end of slab deposition in a location, which in a framework of vertical sinking coincides with the arrival of the continental margin. The westward-up slope of the eastern slab walls in Figure $4 \mathrm{~b}$, from red through yellow to green levels, can thus be quantitatively correlated with the trajectory of North America's westward drift (recorded by the Atlantic's fully preserved spreading record of isochrons and its anchoring to the hotspot frame of the lower mantle). This correlation yields slab sinking values of $\sim 10 \mathrm{~mm} /$ year for all parts of the slab walls, verified against key events in the geologic record of Cordilleran collisions (details in Sigloch and Mihalynuk, 2013). Therefore, we adopted this sinking rate when importing tomographic depth slices as a time-dependent raster into GPlates, that is, for every 1 Myr time increment, $10 \mathrm{~km}$ of slab are "added" to the $3 \mathrm{D}$ renderings in the style of Figure $4 \mathrm{~b}$.

\section{Results}

The main result of this study is the digital plate reconstruction of western North America and the eastern Pacific that evolves in 1 Myr time intervals (see Supporting Information, Movies S1 and S2). In this section, we summarize the tectonic history of the region, divided into subsections which mark changes in plate configuration, and discuss the key constraints, considerations, and choices that went into producing the reconstruction. The five subsections cover the periods from 170-147, 147-115, 115-83, 83-55, and 55-0 Ma.

The backbones of our trench reconstructions are the massive, linear, wall-like Mezcalera and Angayucham slabs in the lower mantle, which strike continuously for more than $10,000 \mathrm{~km}$ in north-south and northwest-southeast directions (Figures 5 and 6). These slab walls are among the most massive and robustly imaged slabs anywhere in the mantle and were universally presumed to represent Farallon lithosphere since the early tomography of Grand (1994). Crucially, these slabs are located several thousand kilometers west of the Jurassic position of North America, according to all mantle reference frames that make no a priori assumptions about the subduction history of western North America (e.g., Doubrovine et al., 2012; Müller et al., 1993, 2019; Seton et al., 2012; Torsvik et al., 2008, 2012, 2019). Subduction frames that attempt to enforce Andean-style Farallon subduction (van der Meer et al., 2010) do not succeed completely and create contradictions with hotspot tracks (Williams et al., 2015) and lower mantle structure globally (Butterworth et al., 2014; Shephard et al., 2012) (details in Supporting Information and Figure S1).

Sigloch and Mihalynuk $(2013,2017)$ therefore argued that the lower parts of these slab walls were formed by the subduction of two different oceans (the Mezcalera and Angayucham oceans), subducting westward while North America was still located east of the slab walls. As the continent was gradually pulled into these trenches, it overrode and accreted their arcs but continued its westward drift into the realm of the archipelago and of Farallon subduction. As a consequence, subduction was gradually forced to flip to eastward dipping, now under the continental margin ("Andean style"). Sections 3.1 to 3.5 spell out the stages of this archipelago override process, which took 100 Myr to complete.

\subsection{Middle to Late Jurassic (170-147 Ma)}

Global tomography models (e.g., Amaru, 2007; Hosseini et al., 2020; Li et al., 2008; Shephard et al., 2017; Sigloch, 2011) agree that the deepest parts of the Mezcalera and Angayucham slab walls extend roughly to depths of 1,800-2,000 km everywhere along their $>10,000 \mathrm{~km}$ long strike. This points to subduction initiation on a very large scale at the equivalent time, which we identify as being at 180 Ma using a $10 \mathrm{~mm}$ /year sinking rate. The more westerly Cascadia Root slab, into which Farallon plate subducts to present day, extends to the same depth of $\sim 1,800 \mathrm{~km}$ (Sigloch \& Mihalynuk, 2017). Thus, it appears that around 180 Myr ago, the Cordilleran archipelago sprang into being essentially as a whole. Many of its arcs were built on microcontinents (Insular and Guerrero superterranes) that were already hundreds of million years old and had supported generations of earlier arcs—consistent with differently configured slabs in the lowermost mantle, only blurrily imaged at present. Presumably, the preexistence of older terranes in the area shaped the geometries of the archipelago's newly initiated subduction zones.

The Pacific plate triangle started spreading also around $180 \mathrm{Ma}$ (Engebretson et al., 1985; Seton et al., 2012), perhaps as a reaction to the pull of the new Cascadia Root trench on the adjacent Farallon plate. Along the North American margin around the same time, a major geological episode concluded with the final closure of the Cache Creek Ocean (Mihalynuk et al., 2004) - a precursor to or side arm of the Mezcalera Ocean-and the accretion of the Intermontane superterrane (purple in Figure 5) to North America. This occurred at 
Reconstruction at $170 \mathrm{Ma}$
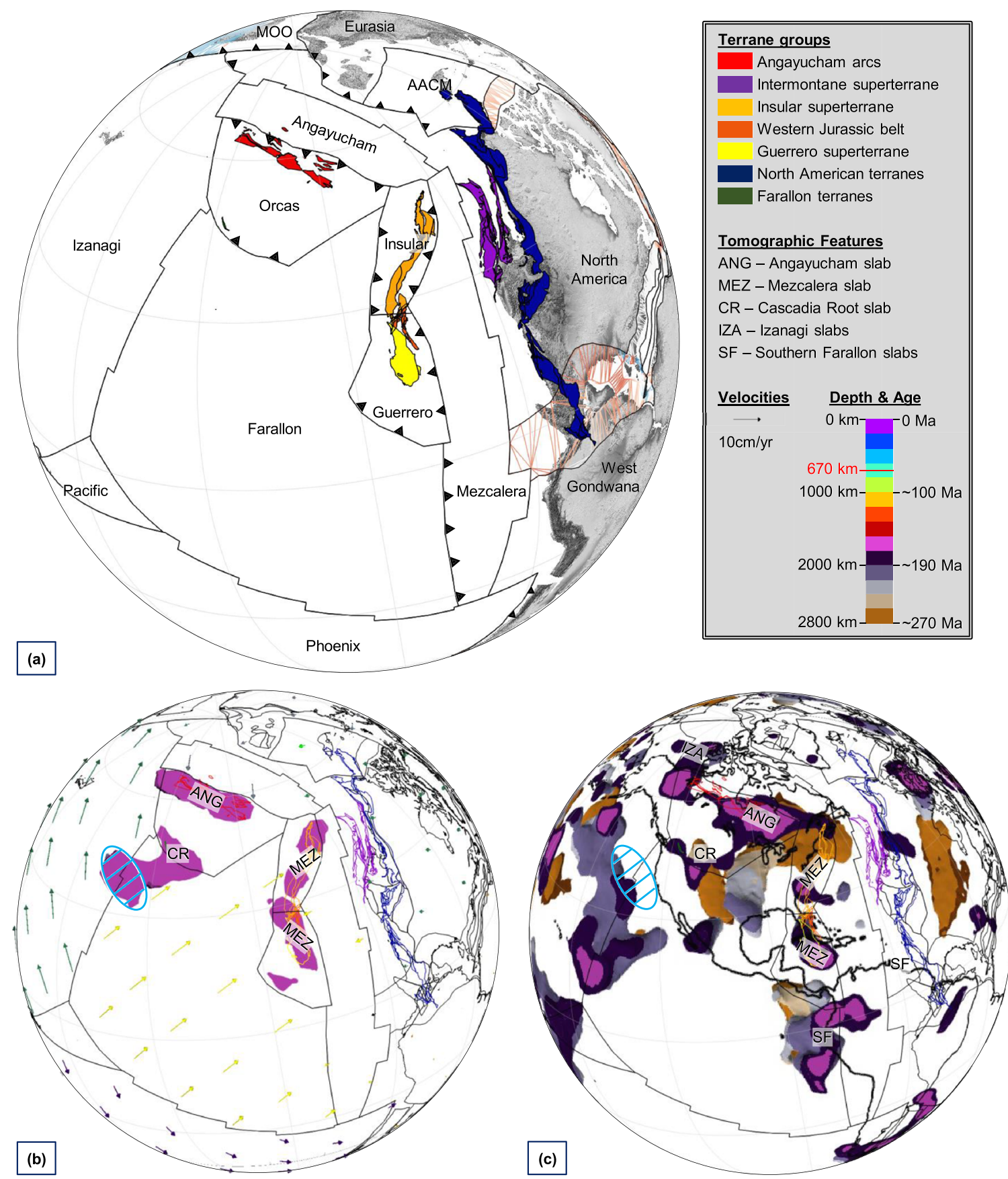

Figure 5. (a) Our plate reconstruction at $170 \mathrm{Ma}$ within the reference frame of Müller et al. (2019), centered at $25^{\circ} \mathrm{N}, 90^{\circ} \mathrm{W}$. Most of the Cordilleran terranes are situated on three plates-the Orcas, Insular, and Guerrero plates. The Farallon plate is shortened compared with conventional reconstructions, subducting into intraoceanic trenches rather than beneath the North American margin. Specifically, the northern Farallon plate subducts beneath the Cascadia Root arc on the Orcas plate, building a robustly imaged slab labeled CR in panels (b) and (c). The southern Farallon plate subducts under the Guerrero and Mezcalera plates. The North American plate and West Gondwana have an oceanic westward extension to a speculative mid-ocean ridge that abuts the Mezcalera Ocean plate. The Mezcalera plate subducts westward underneath the Insular (orange) and Guerrero (yellow) microcontinents. The Angayucham oceanic plate, a northward extension of the Mezcalera Ocean, subducts southwestward underneath the Orcas plate, building the Angayucham arcs of future central Alaska (red). MOO, Mongol Okhotsk Ocean; AACM, Arctic Alaska-Chukotka microplate. (b and c) Plate reconstructions underlain by two tomography models, displayed as color-banded 3D maps. (b) Tomographic constraints from Sigloch_Nam_2011 (Sigloch, 2011) with our plate circuit, superimposed with plate velocity vectors generated in GPlates. (c) Slab constraints from the DETOX-P3 model of Hosseini et al. (2020) with modern continent outlines shown for reference. We do not place a trench above the western CR anomaly (hatched area) as this anomaly is likely a result of upward smearing of some deeper structure-the DETOX-P3 model in panel (c), which resolves the lower mantle more confidently, detects no slab at these depths. 


\section{Reconstruction at $140 \mathrm{Ma}$}
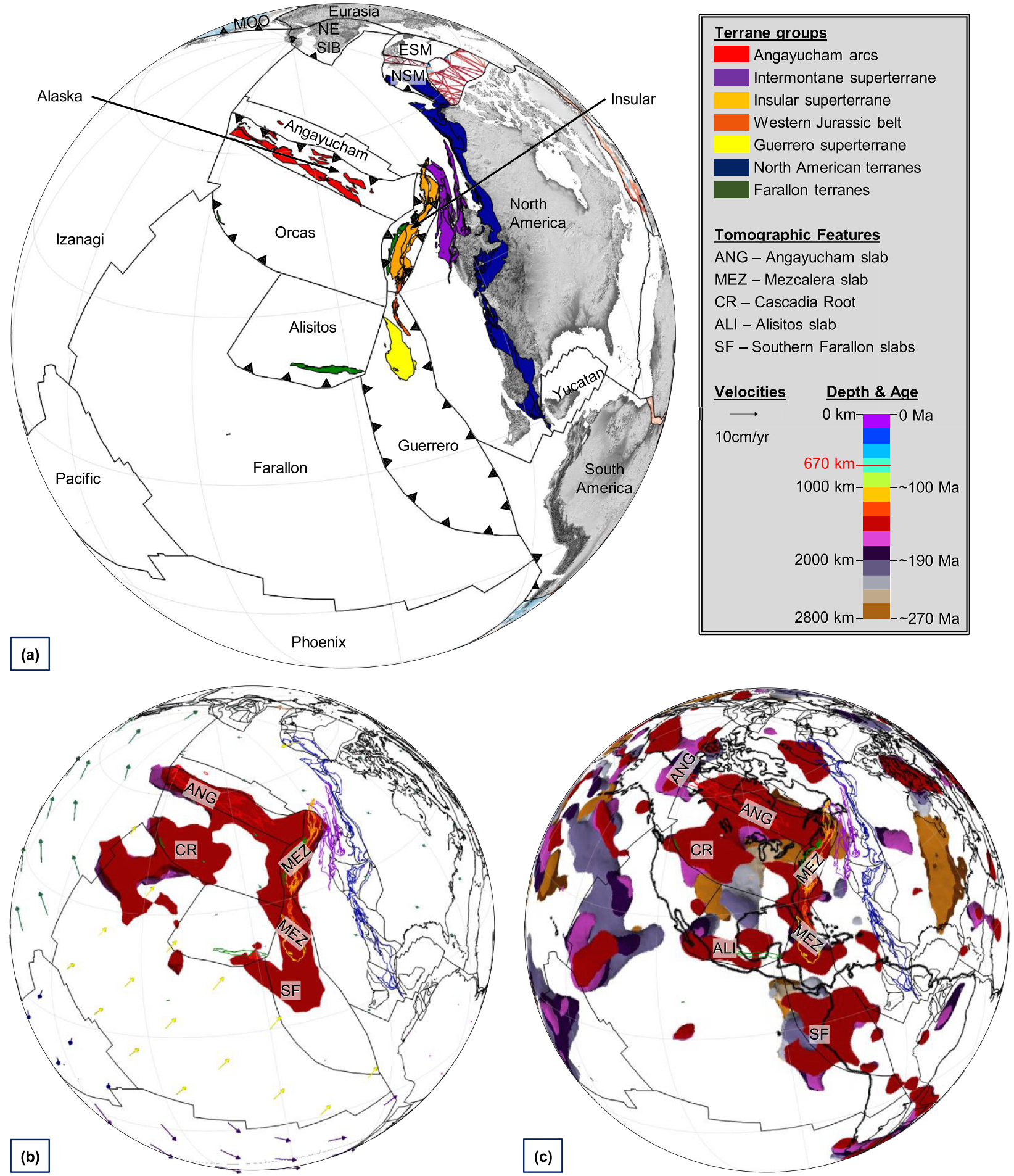

Figure 6. Reconstructed plate circuit and tomography models at $140 \mathrm{Ma}$. Plotting styles as in Figure 5. (a) North America has begun to override the archipelago, resulting in eastward subduction under Insular. The Farallon plate has also begun to subduct into the Alisitos trench, trapping oceanic crust behind it on the Alisitos plate. Proto-Caribbean crust is trapped between the Farallon/Panthalassan and Mezcalera oceans, although presently, it is part of the Guerrero plate. MOO, Mongol-Okhostk Ocean; NE SIB, Northeast Siberia; ESM, East Siberia microplate; NSM, North Slope microplate. (b) The regional tomography model remains largely unchanged compared with $170 \mathrm{Ma}(1,700 \mathrm{~km})$, indicating that the subduction zones remained stationary. However, in (c), the global tomography model shows a massive, east-west trending slab (ALI) beneath present-day Mexico, which we correlate to the Alisitos arc terrane. The southern Farallon slabs cover a wide area in the DETOX-P3 model, which we interpret as being the result of two trenches, much like the present-day Caribbean. 
173 Ma in Canada (Mihalynuk et al., 1994) and slightly later in the western United States, with the Blue Mountains accreting by $160 \mathrm{Ma}$ (LaMaskin et al., 2015).

Our reconstruction starts at $170 \mathrm{Ma}$, when the Mezcalera slab becomes a well-resolved feature in the tomographic images upward of $\sim 1,700-\mathrm{km}$ depth (Sigloch, 2011) (Figure 5b). At this time, the main arcs that formed the convergent margins of the major Middle-Late Jurassic plates were thus established. These subdivide Panthalassa and are separated from North America by an elongate basin, divided into the Angayucham Ocean in the northwest and the Mezcalera Ocean in the southeast. The Mezcalera Ocean, defined as seafloor located between North America and the Mezcalera slab, subducted westward into this slab; we show this ocean subducting westward as no suitable candidate slab is imaged farther east. Analogously, the inferred Angayucham Ocean occupied the reconstructed, sub-Arctic space between North America and the Angayucham arcs, subducting southwestward underneath the Orcas plate, creating the Angayucham slab. Prior to the first arc collisions, the Mezcalera and Angayucham oceans were connected. A speculative spreading ridge separated the Angayucham Ocean, its northeastern half on the North American plate and its southwestern half constituting the inferred "Angayucham plate." A similar mid-ocean ridge probably divided the Mezcalera Ocean basin into an eastern half on the North American plate and a separate half, the inferred "Mezcalera plate."

The Insular superterrane, after which the plate is named, is dominated by the Alexander, Wrangellia, and Peninsular terranes. It has long been debated whether their Mesozoic arcs faced east or west (Dickinson, 2004; Sigloch \& Mihalynuk, 2017). No slabs are imaged east of the Mezcalera slab wall, in locations and depths appropriate for Andean-style subduction along the North American margin at this time (Sigloch, 2011). The implication is that the Jurassic-Cretaceous arcs on Insular were generated by westward subduction of the Mezcalera Ocean into the Mezcalera slab wall.

The Guerrero superterrane is another east-facing island arc complex (Dickinson \& Lawton, 2001) and can therefore be considered a southern extension of Insular (Sigloch \& Mihalynuk, 2013, 2017). We also place the Western Jurassic belt of Dickinson (2008) on the Guerrero plate. Comprising the Western Klamath Mountains, Great Valley basement, and the northern Sierra Nevada, this is another Insular-associated terrane and is currently situated between Insular and Guerrero, so it is maintained at this position between the two superterranes at $170 \mathrm{Ma}$.

The Insular-Guerrero plate boundary is inferred to have been a rift system that accommodated the $10^{\circ}$ of paleomagnetically indicated northward drift of the Insular plate during the lower Jurassic (Kent \& Irving, 2010). Middle-Late Jurassic rifting between Insular and Guerrero would predict the formation of an ocean basin in between, which has not been previously proposed. We suggest that this is the birthplace of two Late Jurassic ophiolite complexes, the 161 Ma Ingalls ophiolite on the southern margin of Insular (MacDonald et al., 2008) and the 162 Ma Josephine ophiolite in the Klamath Mountains of the Western Jurassic belt (Harper et al., 1994). Both the age and the location of these relicts of ocean crust are consistent with formation in this hypothesized basin.

The most significant departure from previous models concerns the Farallon plate. In traditional reconstructions (e.g., Engebretson et al., 1985; Müller et al., 2019), the Farallon plate extended eastward to the North American margin, whereas we propose that it subducted underneath new oceanic plates of the Cordilleran archipelago, west of North America. The northernmost Farallon plate has continuously subducted beneath the Orcas plate into the Cascadia Root trench from 180 Ma up until present day; this trench was intraoceanic until it was overridden by continental North America, at latitudes of Oregon, Washington, and British Columbia, in the Eocene. The southern Farallon plate subducted underneath the Mezcalera and Guerrero plates, into a trench that joins up to the Phoenix ridge, constrained by southern Farallon slabs imaged by Hosseini et al. (2020).

However, there is a significant gap in subduction between the imaged Cascadia Root slab and southern Farallon slabs. This corresponds with a widening at the northern end of the Mezcalera slab at 1,500-km depth (Figure 6), which could indicate subduction from two sides into the northern Mezcalera slab at this time. Thus, we propose that a narrow section of the Farallon plate, bounded by two transform faults, is subducting eastward into this northern Farallon trench.

Further changes were made to surrounding plates to ensure that the regional reconstruction is consistent with the Müller et al. (2019) global model. These changes include closing the Izanagi plate to 
the north with a transform boundary along the Orcas plate. In addition, we added a subduction segment above the IZA slab (Figure 5c) to accommodate convergence with the North American plate, which is extended to include the Angayucham Ocean. In the southeast, the West Gondwana plate is extended to include half of the Mezcalera Ocean, and it is closed to the south with a trench boundary with the Phoenix plate.

\subsection{Early to Middle Cretaceous (147-115 Ma)}

Around $147 \mathrm{Ma}$, there is a period of widespread tectonic change in Panthalassa, with a $24^{\circ}$ rotation of the Pacific-Izanagi spreading ridge, contemporaneous with eruption of the Shatsky rise at the PacificFarallon-Izanagi triple junction (Sager et al., 1988; Seton et al., 2012). As part of this tectonic change, we show a major reorganization of the intraoceanic plates with the initiation of Farallon subduction at the Alisitos trench. This corresponds to a distinct east-west trending slab upward of $1,400 \mathrm{~km}$, under present-day Mexico (labeled ALI in Figure 6c). This slab meets the established, north-south striking southern Farallon trench at a right angle-similar to the nature of the current Pacific boundary at the western Aleutians. The ALI slab has a similar strike to the Cascadia Root slab, and we connect these two implied trench segments with a transform fault. Tomotectonic correlation of the ALI slab is with the Alisitos arc terrane, a second arc outboard of the Guerrero superterrane of present-day Mexico. Alisitos' earliest volcanic rocks are dated to approximately $140 \mathrm{Ma}$ (Johnson et al., 1999)_allowing a few million years for melt production following subduction initiation.

Latest Jurassic is when North America collides with the Mezcalera arc, initially at its northeastern end. The timing of collision, as inferred from superposition of plate reconstructions and slab walls, is consistent with the onset of suturing along the length of the Cordillera (Sigloch \& Mihalynuk, 2017) as well as the timing of Nevadan and Sevier deformation (DeCelles, 2004; Harper et al., 1994). Hence, our tomotectonic correlation places the Insular superterrane along the northern segment of the Mezcalera slab. The geometries of the slab and the continental margin predict diachronous accretion of the Insular superterrane, beginning in the north. This geometric constraint requires anticlockwise rotation of Insular superterrane as accretion proceeds from north to south, which matches paleomagnetic data suggesting anticlockwise rotations of Insular superterrane prior to the mid-Cretaceous (Irving \& Wynne, 1991) and would also explain why dextral transpressional regimes are observed in Alexander (McClelland et al., 1992).

A consequence of this collision is a flip in subduction polarity along the accreted Insular superterrane, such that Orcas oceanic crust west of Insular now subducts eastward under the newly configured North American margin (Sigloch \& Mihalynuk, 2013). This commencement of eastward subduction is recorded in the Chugach accretionary complex, which is dated to $146 \mathrm{Ma}$ based on depositional ages of detrital zircons (Amato \& Pavlis, 2010). As this polarity switch likely resulted in new slab pull forces acting on the Orcas plate, we implemented a small amount of eastward motion for this plate. This would require that the transform boundary with the Izanagi plate converted to a spreading ridge and that the Orcas plate was bound to the south and north by transform faults that accommodated the relative motion with the Alisitos and Alaskan plates.

Another accretionary complex that records Farallon plate subduction is the Franciscan complex of California, which began to show accretionary behavior at $123 \mathrm{Ma}$ (Dumitru et al., 2010). We place this subduction complex outboard of the Alisitos arc at this time. Paleomagnetic studies of the Laytonville (Alvarez et al., 1980; Tarduno et al., 1990) and Calera (Tarduno et al., 1985) limestone blocks within the Franciscan complex require unrealistic Farallon plate velocities based on the accretion ages of these rocks, but a more southerly paleoposition for the Franciscan complex, matching paleolatitudes of the Alisitos trench, would resolve this problem.

At $120 \mathrm{Ma}$, a block of old oceanic crust breaks off from Guerrero, separated by a transform boundary. This break is apparent in the tomography where there is an east-west termination of a wide region of fast anomalies (Figure 7c) and is consistent with the relative motion of North America along this boundary. The plate stops migrating at around $104 \mathrm{Ma}$ close to the region where Seton et al. (2012) propose the Caribbean plate originates. This suggests that the oceanic crust bounded by the southern Farallon and Mezcalera trenches plays an important role in the evolution of the Caribbean plate. 
Reconstruction at $110 \mathrm{Ma}$

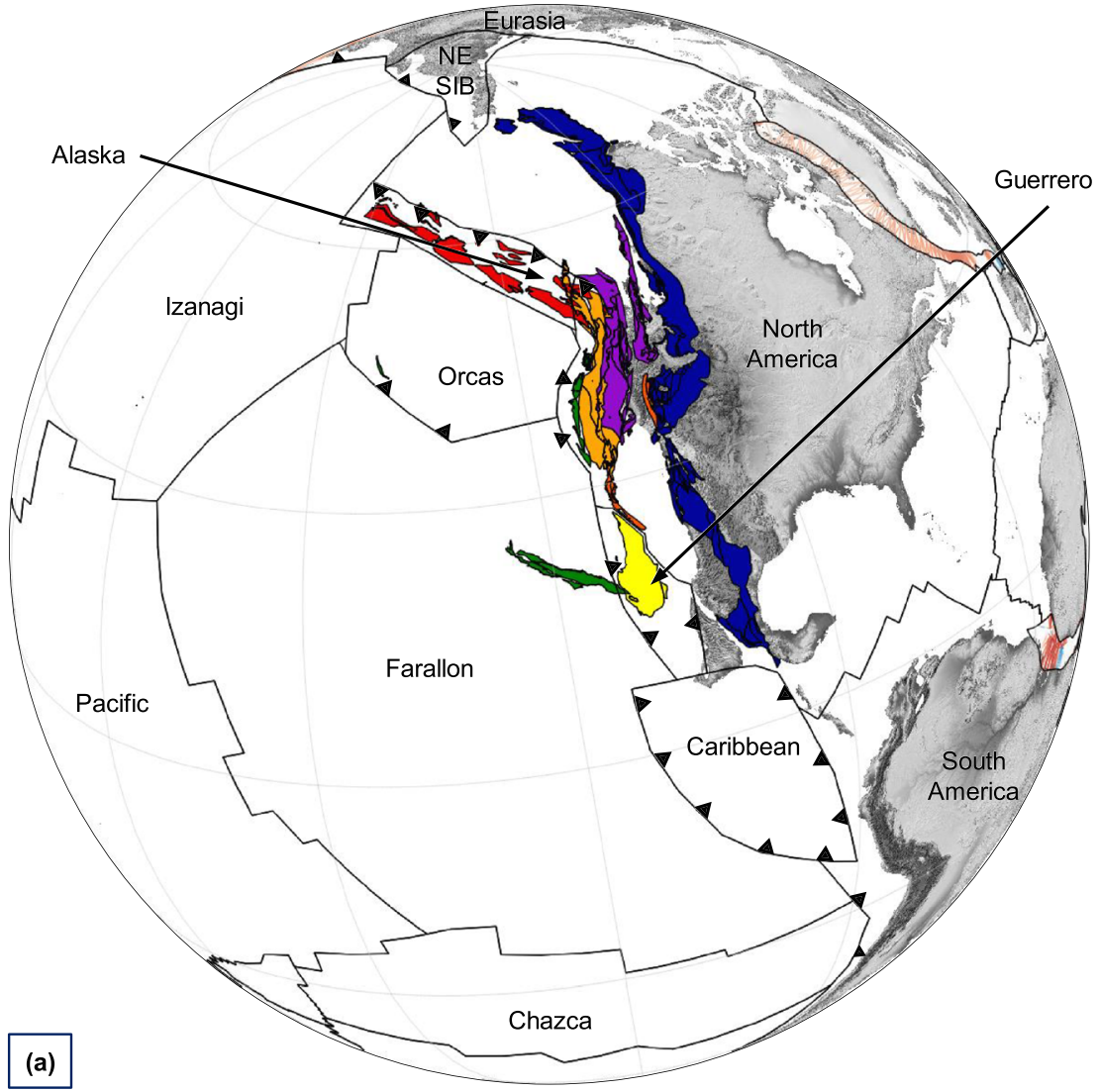

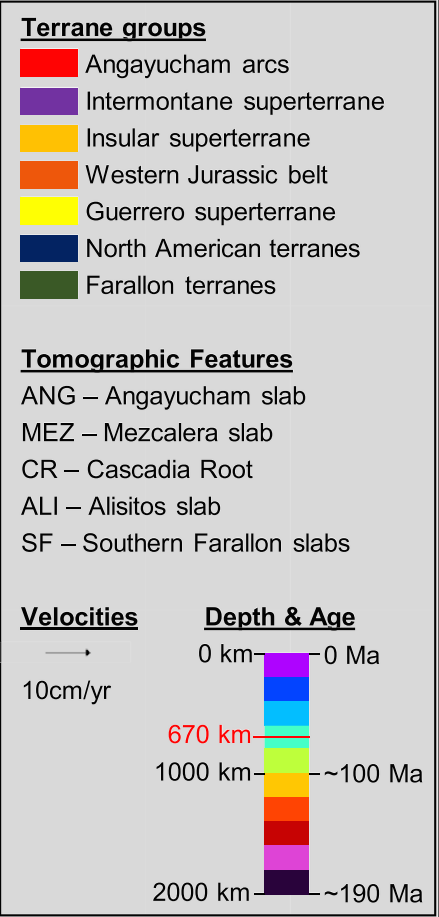
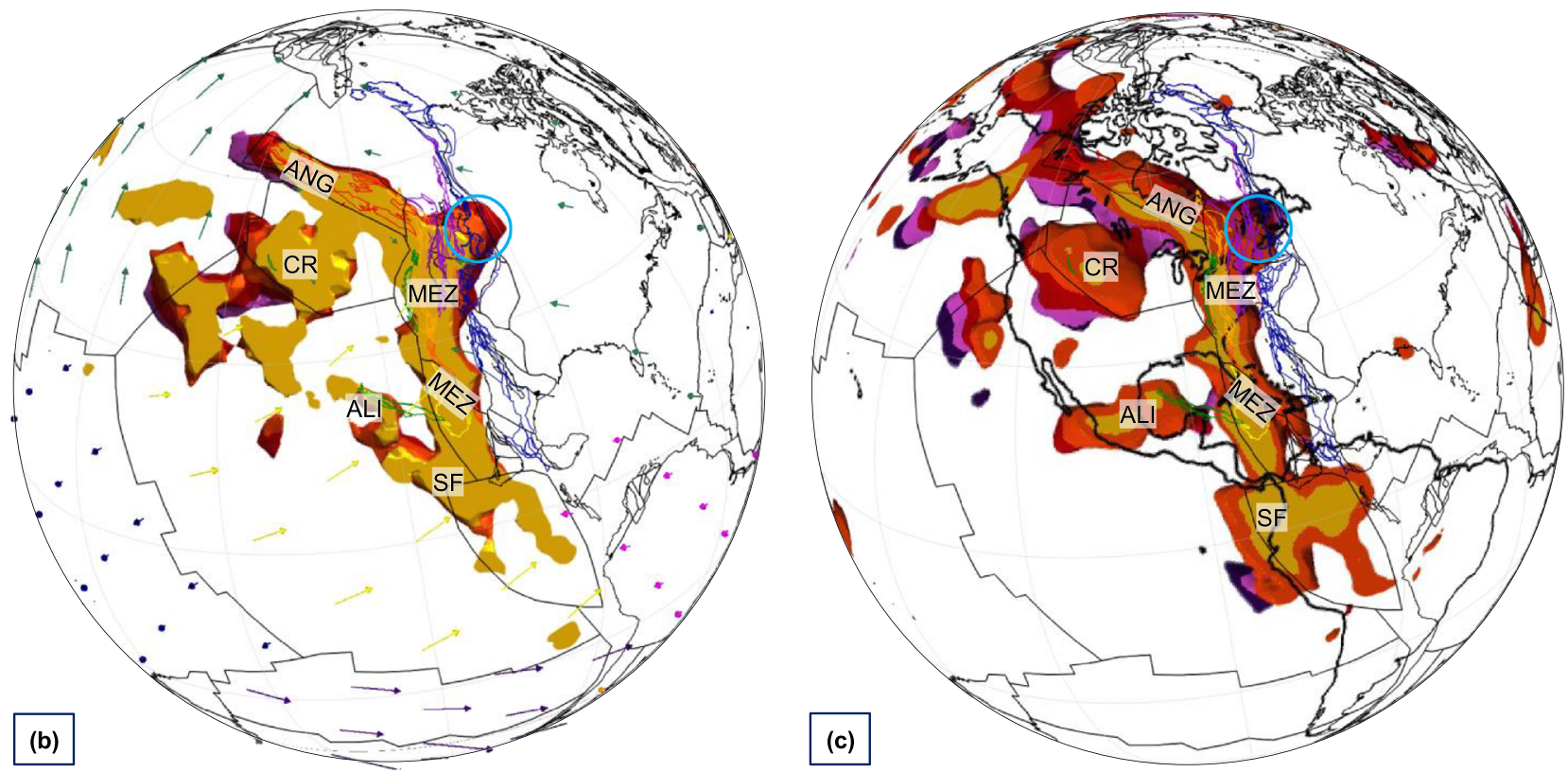

Figure 7. Reconstructed plate circuit and tomography models at 110 Ma. Plotting styles as in Figure 5, except that panel (c) now shows the DETOX-P1 tomography model. (a) The Insular superterrane along the northern MEZ slab has accreted to North America. In the south, the Mezcalera Ocean is almost closed, accreting Guerrero superterrane to North America. The Alisitos terrane is accreting to Guerrero following the shutdown of the Alisitos trench. NE SIB, Northeast Siberia. (b) Active subduction zones correspond to orange slab surfaces. The override of the northern Mezcalera trenches is reflected in the upward truncation (circled) of northeastern MEZ slab at red levels. (c) The DETOX-P1 model also shows upward truncation of the ALI slab at this depth, representing extinction of the Alisitos arc. 


\subsection{Middle to Late Cretaceous (115-83 Ma)}

The completed override of northeastern Mezcalera arcs (Insular superterrane) is reflected in the easternmost MEZ slab no longer growing. The actively building (orange, Figures $7 \mathrm{~b}$ and $7 \mathrm{c}$ ) slab contour has moved west at these latitudes and is now fed by eastward subduction of archipelago (Orcas) lithosphere. Andean-type subduction of oceanic lithosphere beneath western United States at these times is recorded by widespread Cretaceous plutonism, such as in the Sierra Nevada Batholith (Ducea, 2001). Also during mid-Cretaceous times, the Western Interior Seaway formed, which we interpret as a flexural response to crustal thickening of the Intermontane superterrane and loading of the continental margin-much like the present-day Gulf of Carpentaria (Sigloch \& Mihalynuk, 2017).

Further south along the MEZ slab, the westward-subducting Mezcalera Ocean is finally closing and Guerrero superterrane begins to accrete to North America during the Early Cretaceous (Dickinson \& Lawton, 2001). At this time, we show Mexico lying due south (rather than southeast) of California according to paleomagnetic declinations that suggest that Mexico has rotated anticlockwise by $40^{\circ}$ since the Late Cretaceous (Urrutia-Fucugauchi, 1981). The resulting, more westerly location of Mexico gives a straighter continental margin that permits a mid-Cretaceous collision with southern Mezcaleran terranes (Guerrero superterrane and Western Jurassic belt), which occurs at $110 \mathrm{Ma}$ in our model. However, there are overlapping carbonates that extend across both Guerrero and nuclear Mexico of 120 Ma age (Dickinson \& Lawton, 2001) and plutons that stitch the NW Sierra Nevada at 130-125 Ma (Dickinson, 2008), suggesting that the Mezcalera Ocean should have closed 10-20 Myr earlier than shown in our reconstruction. This consistent issue is most likely due to poor longitude constraints in the absolute reference frames, at a time when the oldest Atlantic hotspot tracks peter out. In addition, we show all terranes and the continental margin in their present-day shapes, shortened by compression; originally, they would have extended further west (DeCelles \& Coogan, 2006), implying earlier collision times, as observed.

Here as well, subduction polarity was forced to flip to eastward as North America overrode the southern MEZ slab. This flipped subduction would have pulled in lithosphere from the vicinity of Alisitos arc. This may well be the reason that subduction into the Alisitos trench begins to shut down at $115 \mathrm{Ma}$ (Johnson et al., 1999). An alternative or additional reason could be a collision of the conjugate of the Shatsky Rise with the island arc, which is predicted to occur about this time. Subsequent effects of Shatksy Rise conjugate collision were widespread in southwest United States, including choking Sierra Nevadan arc subduction, scouring away the sublithospheric mantle (Grove et al., 2008; Humphreys et al., 2003) and causing the basement uplifts of the Laramide orogeny at around 85-55 Myr ago (Livaccari et al., 1981).

Initially, the Alisitos terrane (green, Figure 7a) travels northward on the Farallon plate, but once its eastern edge collides with the Guerrero superterrane, it begins to rotate clockwise into the superterrane. This rotation likely contributes to the variations in deformation style along the length of the Alisitos terrane (Wetmore et al., 2014). Accretion is completed by $103 \mathrm{Ma}$, the age of intrusions that cut the Main Mártir Thrust suture (Johnson et al., 1999).

Another important terrane collision that began in the late Early Cretaceous is the "Great Alaskan Terrane Wreck" (Johnston, 2001). Initially, the Alaskan arcs were strung out along the Angayucham arc. However, as the North American continent arrived at the edge of the trench at $110 \mathrm{Ma}$, the terranes began to buckle and rotate, accommodating shortening while allowing oblique subduction of the Angayucham Ocean to continue.

\subsection{Late Cretaceous and Paleocene (83-55 Ma)}

At $83 \mathrm{Ma}$ (Figure 8), the Kula plate broke from the Pacific, Farallon, and Izanagi plates as constrained by east-west trending magnetic lineations in the northern Pacific (Atwater, 1989). The orientation and approximate life span of the Kula-Pacific ridge are the only constraints on the Kula plate from surface observations. Starting from the proposals of Engebretson et al. (1985) and Müller et al. (2019), we edited the remaining geometries of the Kula plate to ensure consistency with constraints from seismic tomography and paleomagnetism. We place the Kula trench above the KUL slab located north of the Kula spreading ridge. The subduction zone continues westward into the IZA slab, the presumed trench location of the Izanagi plate, from which the Kula plate is thought to have broken off in part. This trench solution seems simple and intuitive in conjunction with the surface constraint, but we note that the KUL and IZA slabs are located 200-300 km 


\section{Reconstruction at $80 \mathrm{Ma}$}

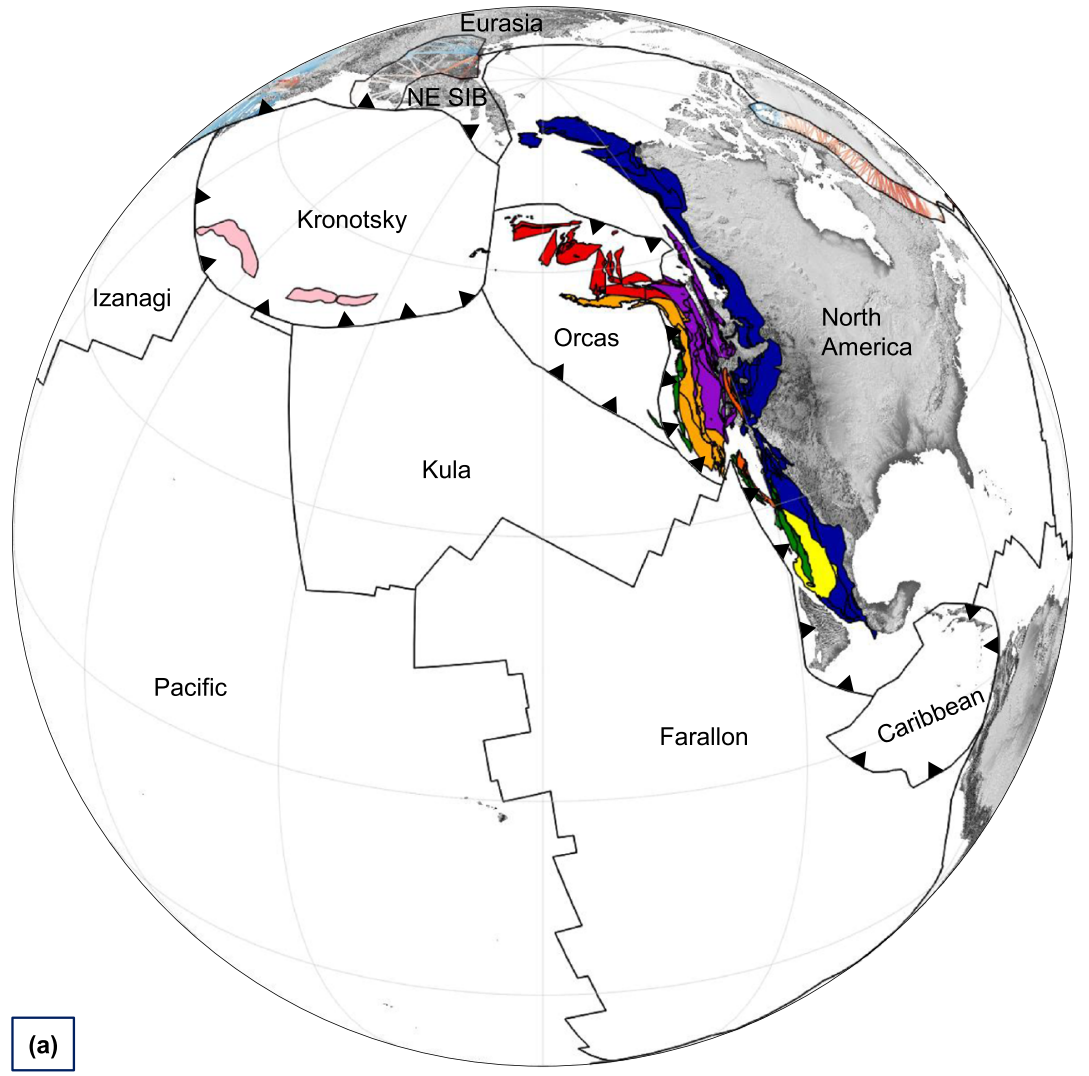

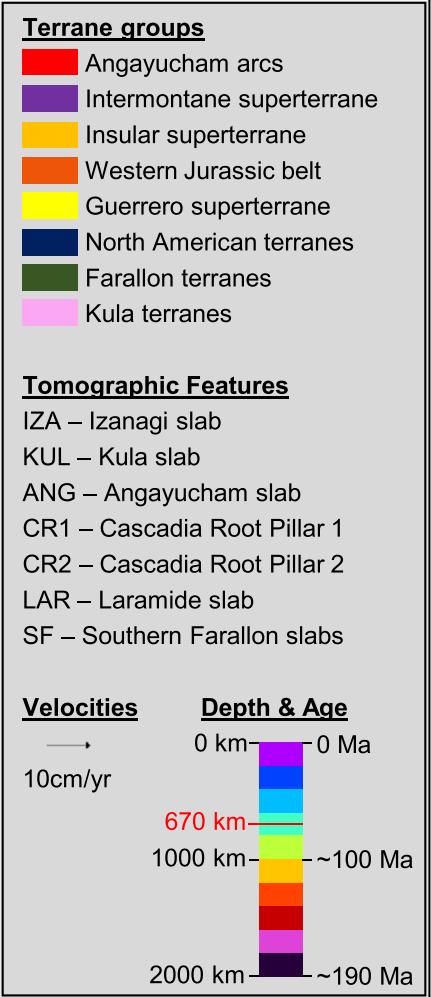
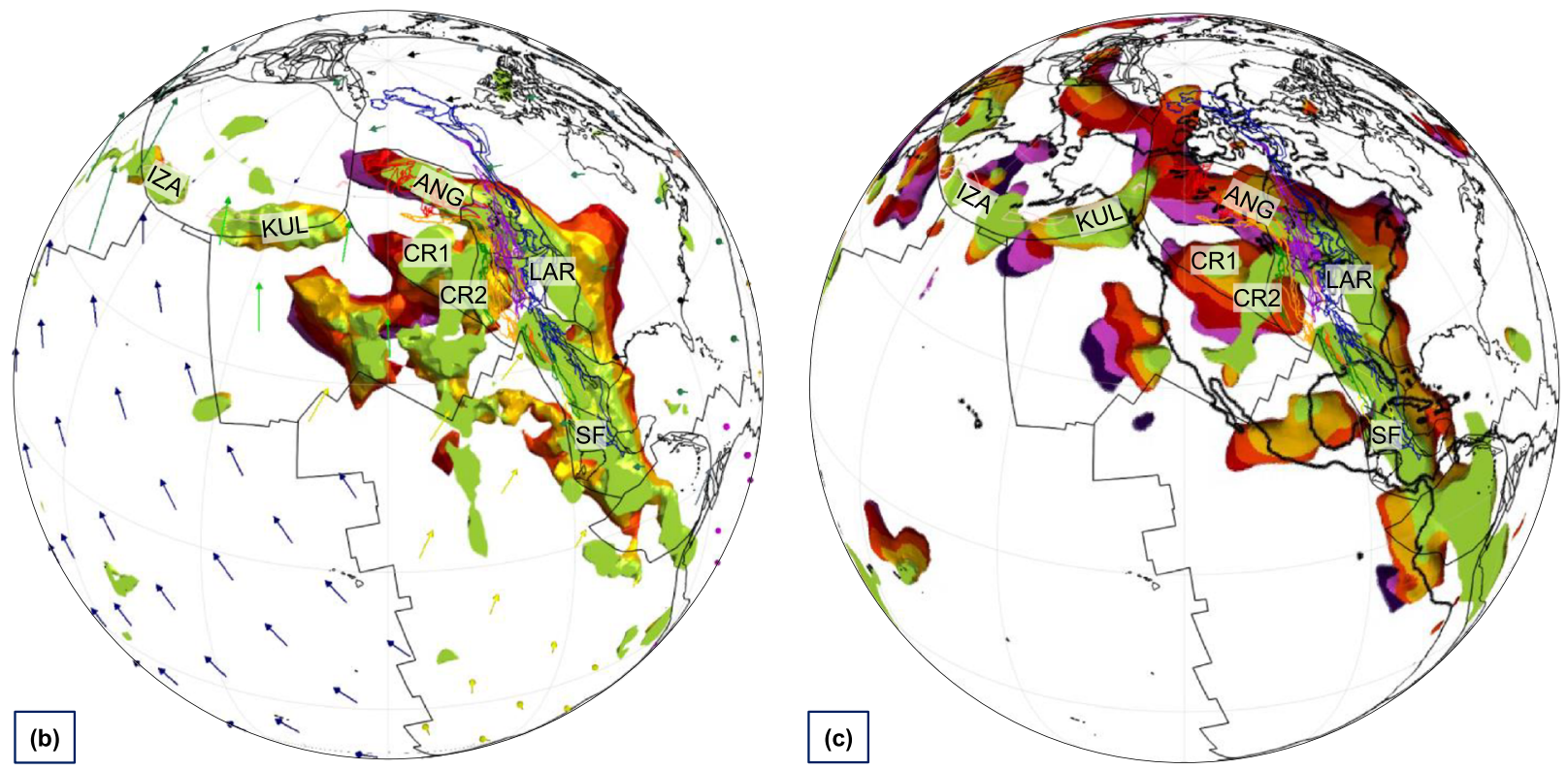

Figure 8. Reconstructed plate circuit and tomography models at $80 \mathrm{Ma}$. Plotting styles as in Figure 7 except that the projection is now centered at $30^{\circ} \mathrm{N}, 120^{\circ} \mathrm{W}$. (a) Oblique closure of the Angayucham Ocean continues, causing increased buckling of the Angayucham arcs. The Kula plate has broken off from the Pacific,

Farallon, and Izanagi plates. It subducts primarily northward under the Orcas plate, feeding the Cascadia Root slab (CR1, CR2), and under the Kronotsky plate, which contains the Kronotsky and Olutorsky arcs. NE SIB, Northeast Siberia. (b and c) Active subduction zones correspond to green slab surfaces. Two slabs, Kula (KUL) and Cascadia Root (CR1), constrain the subduction zones of the Kula plate at this time, and the KUL subduction zone extends west into the trench of the Izanagi plate (IZA slab). MEZ slab is completely overridden; its continued growth is fed by eastward subduction of the Farallon and Kula plates. The locations of slab deposition now roll westward with the continent, in contrast to the wall-like slabs that grew under the stationary, intraoceanic Mezcalera trench. 
deeper than expected using an average slab sinking velocity of $10 \mathrm{~mm} /$ year. This would point to a faster sinking rate for this isolated slab (Sigloch \& Mihalynuk, 2017).

Domeier et al. (2017) correlated the KUL and IZA slabs to two arc terranes now accreted to Kamchatka-the Kronotsky and Olutorsky arcs (pink terranes, Figure 8). We tentatively link these on a single plate: the Kronotsky plate. This solution differs from the two-plate proposals by Domeier et al. (2017) and Vaes et al. (2019) and certainly merits further tomotectonic investigation.

We implement the Prince William subterrane as another Kula-affiliated block. Prince William is part of the Chugach subduction and accretionary complex of southern Alaska but can be separated because of its welldefined, Late Cretaceous to Paleogene sediments and arc volcanics, deposition of which overlaps the timing of Kula subduction (Garver \& Davidson, 2015). In contrast, the other blocks of the Chugach terrane are located outboard of Wrangellia during the Late Cretaceous (Garver \& Davidson, 2015). Chugach and Prince William would have merged when incipient Aleutian subduction, the northerly successor of Kula subduction, pulled the extinct Kula arc beneath the southern Alaskan margin.

The Late Cretaceous is the time during which much of the western Canadian Cordillera, termed "Baja British Columbia" (Baja BC), is hypothesized to have been translated thousands of kilometers northward along the continental margin (Irving, 1985). This hypothesis proposes 2,100 $\pm 700 \mathrm{~km}$ of northward translation of Insular and Intermontane, based on extensive paleomagnetic evidence from several accreted terranes showing anonymously shallow inclinations prior to $70 \mathrm{Ma}$ compared with cratonic North America (Enkin, 2006). Accordingly, we implemented northward motion into the rotation files for Insular and Intermontane. As the two superterranes drive into Alaska, the Angayucham terranes further buckle, as best appreciated in our Movies S1 and S2. This forms the main stage of oroclinal orogeny in central Alaska: the "Great Alaskan Terrane Wreck" (Johnston, 2001).

Baja BC translation between 70 and 50 Ma led Engebretson et al. (1985) to suggest that these superterranes were partially coupled to the Kula plate. Therefore, we place the Kula-Farallon spreading ridge just south of the Insular-Intermontane terrane package (Figure 9a). Our ridge is further south than in the Müller et al. (2019) model so that the Kula and Orcas plates provide a driving mechanism for the northward translation of Baja BC. The terranes are translated exclusively on the Orcas plate, a microplate separate from the Kula plate that contains old trapped ocean crust, Angayucham arcs and Farallon-Kula arcs. From 70 to $50 \mathrm{Ma}$, we extend the Orcas plate down to the Kula-Farallon ridge, consistent with an approximate age for a disruption in Cascadia subduction reflected in Cascadia Root slab geometries (Sigloch et al., 2008). At this time, both the western and southern Orcas plate margins are spreading ridges. They migrate eastward (in Alaska) and southward (in Cascadia) to produce progressions of near-trench magmatism, as outlined by Haeussler et al. (2003), who named the inferred plate bound by these two ridges the "Resurrection plate" following Miller et al. (2002). In their model, the Resurrection plate presumably originated as a fragment of either the Kula or Farallon plate, but our analysis reveals Resurrection plate events as the final, override stage in the Orcas plate's much longer existence. The early history of the Orcas plate was much different; it acted as the substrate for arcs formed by subducting Angayucham and Farallon ocean lithosphere since at least $170 \mathrm{Ma}$.

As before, the Orcas plate is bounded in the north by the Angayucham trench. To accommodate the dextral strike-slip motion of Baja $\mathrm{BC}$ along the continental margin, we digitized a transform inboard of Intermontane as the Orcas plate's eastern plate boundary. We implemented a further northward translation of the Chugach terranes along the outboard margin of Insular. Garver and Davidson (2015) hypothesized that Chugach lay alongside Wrangellia during the Late Cretaceous, yet it is now juxtaposed against the Peninsular terrane, having experienced even larger dextral displacements. This suggests that a wide shear zone accommodated Baja BC translations, with the outboard terranes most strongly coupled to the Orcas plate, and the inboard terranes, such as Cache Creek and Quesnellia, more closely coupled to the craton.

From $70 \mathrm{Ma}$, we have implemented a $40^{\circ}$ anticlockwise rotation of Mexico, based on paleomagnetic and geological evidence (Urrutia-Fucugauchi, 1981). This is probably driven by relative eastward motion of the Caribbean plate, which begins at $70 \mathrm{Ma}$ (Seton et al., 2012) as it was squeezed between North and South America. 


\section{Reconstruction at $60 \mathrm{Ma}$}

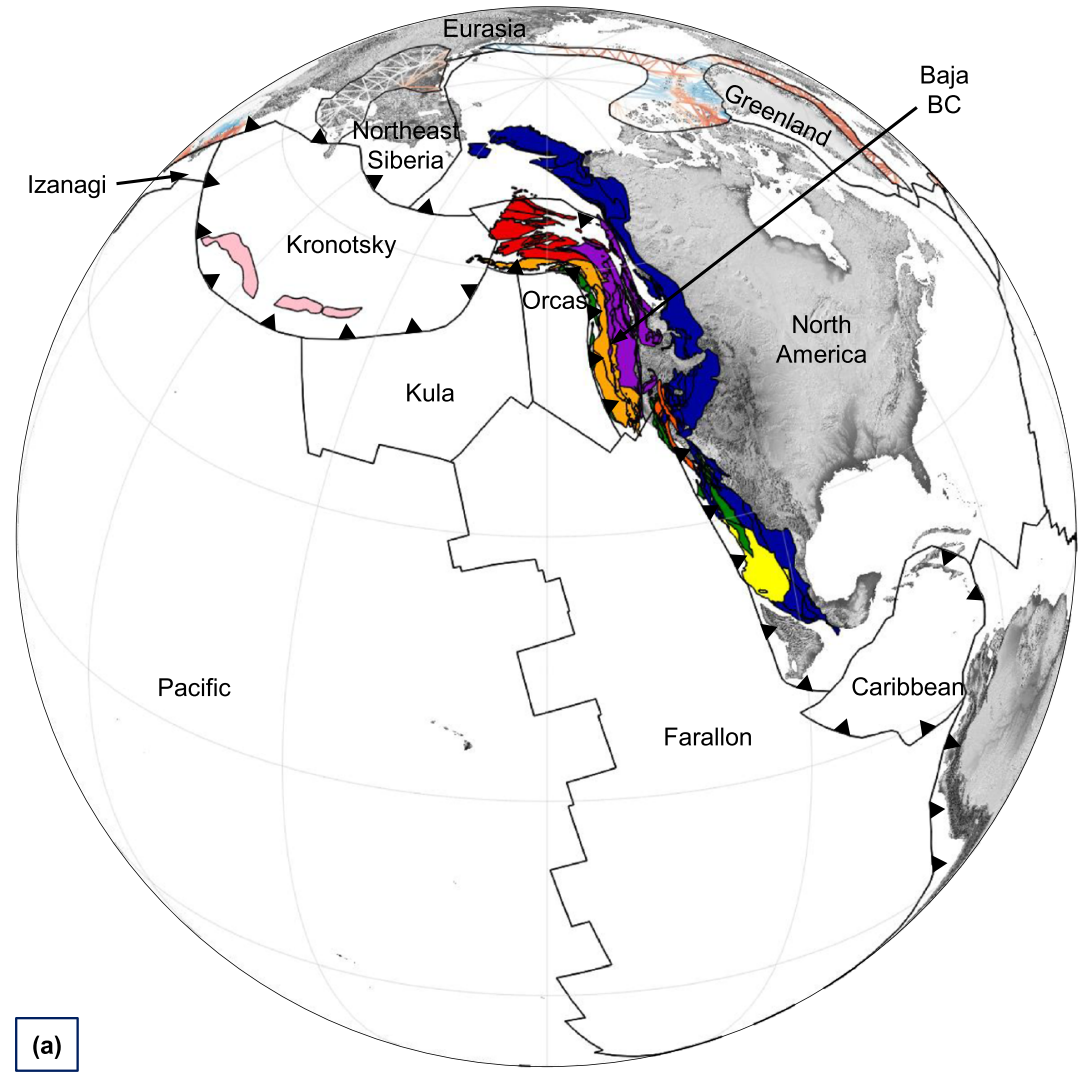

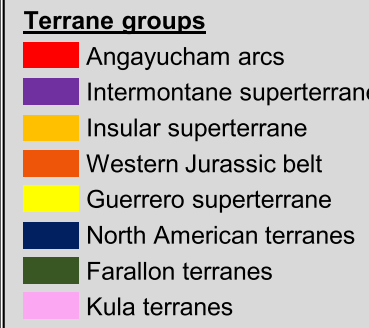

Tomographic Features

IZA - Izanagi slab

KUL - Kula slab

ANG - Angayucham slab

CR1 - Cascadia Root Pillar 1

CR2 - Cascadia Root Pillar 2

LAR - Laramide slab

SF - Southern Farallon slabs

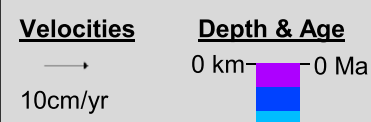

$670 \mathrm{~km}$

$1000 \mathrm{~km}-$

$-\sim 100 \mathrm{Ma}$

$2000 \mathrm{~km}-\sim 190 \mathrm{Ma}$
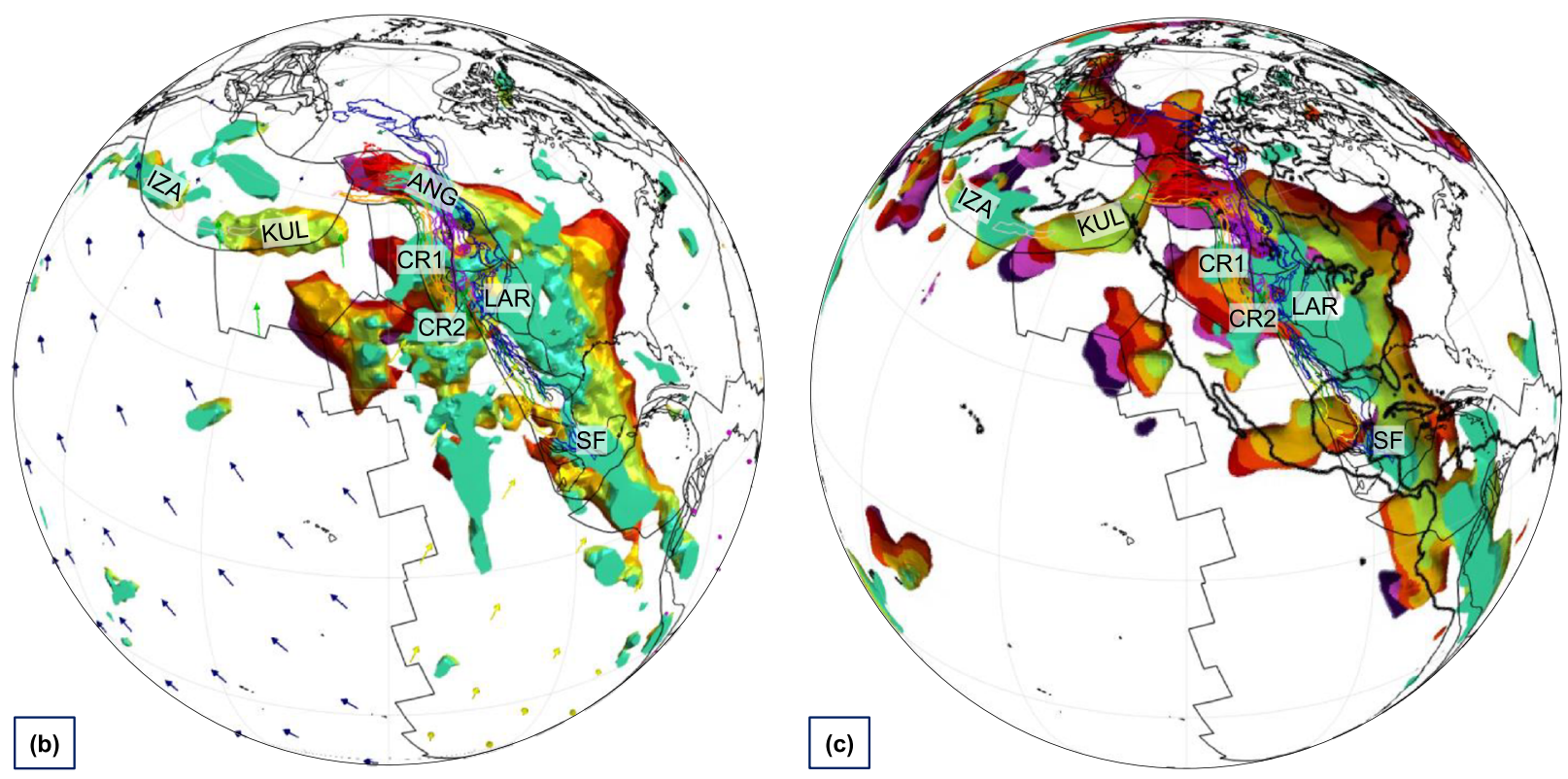

Figure 9. Reconstructed plate circuit and tomography models at $60 \mathrm{Ma}$. Plotting styles as in Figure 8. (a) Spreading between the Kula and Orcas plates and the Farallon plate drives the Cordilleran "Baja BC" terranes northward. This causes further terrane buckling of the future central Alaskan terranes, behind the Angayucham trench which is consuming the last remnants of the Angayucham Ocean. Mexico rotates anticlockwise, driven by movement of North America past the Caribbean plate. (b) Active subduction zones correspond to turquoise slab surfaces. Slabs deposited beneath the "Andean-style," westward-migrating Farallon trench are seen to be smeared westward. A significant discrepancy in slab imaging concerns a north-south striking slab due south of CR2 which is present in the regional model (b) and absent in the global model (c). We choose not to interpret this fast anomaly as it is located at the edges of the regional model and it would be geodynamically unfeasible to build slabs directly above a spreading ridge. It probably represents an artifact of the regional inversion. 


\section{Reconstruction at $30 \mathrm{Ma}$}
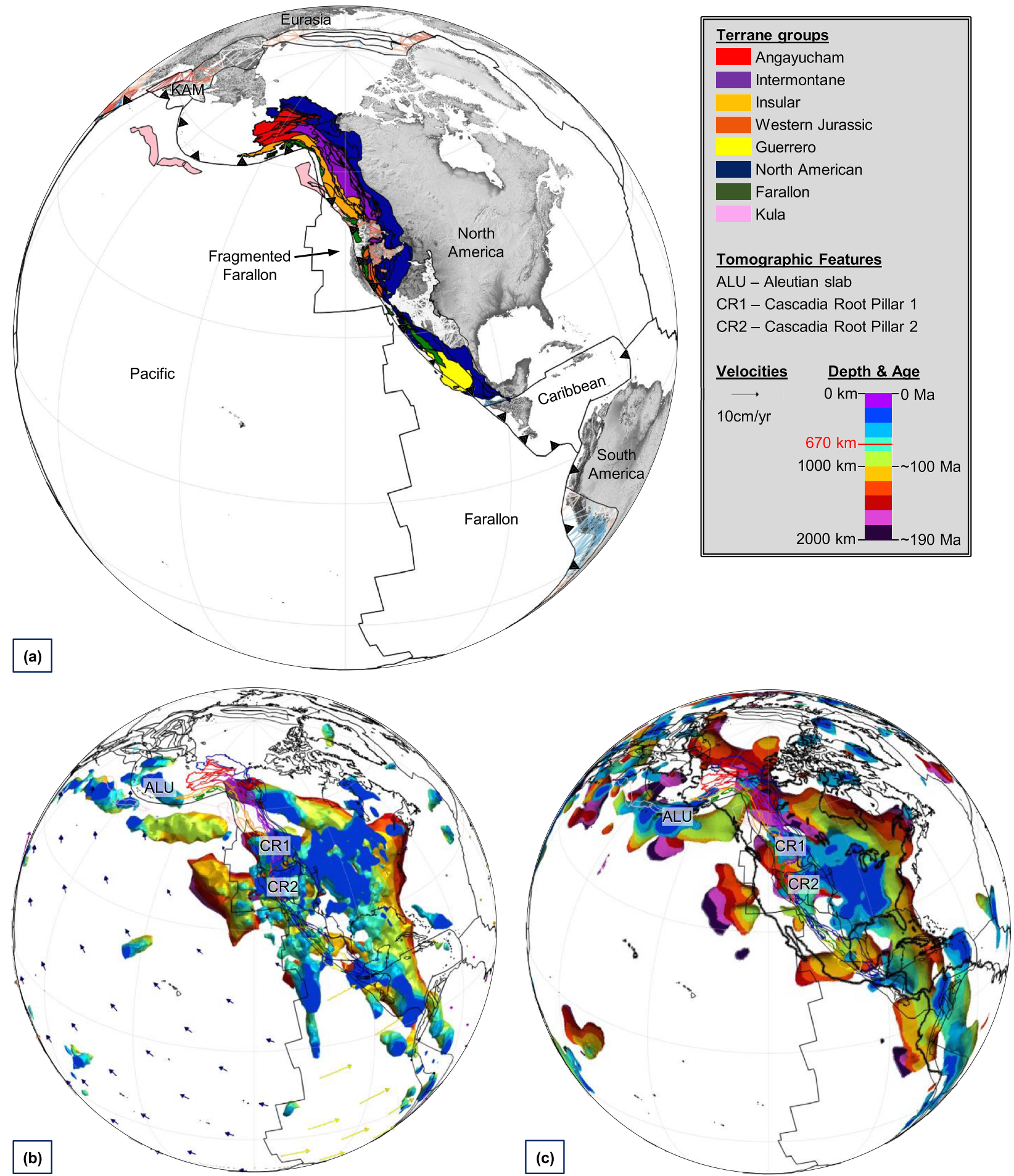

Figure 10. Reconstructed plate circuit and tomography models at $30 \mathrm{Ma}$. Plotting styles as in Figure 8. (a) North American terranes have accreted to the continent and Mexico also reaches its present-day orientation with respect to North America by this time. The Kronotsky plate has shut down; thus, the Kronotsky and Olutorosky terranes are transported on the Pacific plate towards Kamchatka (KAM). (b) Active subduction zones correspond to dark blue slab surfaces.

Subduction of the north Pacific is now into the Aleutian trench, marked by the new Aleutian (ALU) slab. Continued growth of the eastward-dipping CR1 and CR2 slabs under the Cascadia margin records continued subduction of northern Farallon plate fragments (Vancouver, Juan de Fuca). Fast anomalies beneath the East Pacific Rise, offshore Mexico, should not be interpreted as products of subduction; they are absent in the DETOX-P1 model. (c) The global tomography resolves less detail of the relatively narrow Cenozoic slabs in the upper mantle. 
The northward translation of the Cordilleran terranes versus the southeast-directed shearing of Mexico, separated by the Kula-Farallon spreading ridge, provided space for accreted terranes that now reside in California and Oregon, such as the Franciscan complex and Western Jurassic belt. Northward translation of the Franciscan terrane relative to North America, from an initial position outboard of Alisitos arc terrane, continued through the Cenozoic, driven by oblique subduction of the Farallon plate (Tarduno et al., 1985).

\subsection{Eocene to Present (55-0 Ma)}

At $55 \mathrm{Ma}$, southwestward subduction into the Angayucham trench ceases, marking the completion of archipelago override by North America (Sigloch \& Mihalynuk, 2013). At this time, we also show eruption of oceanic plateaus at the Orcas-Farallon ridge: the Yakutat block subsequently moves northward on the Kula plate towards Alaska, while Siletzia accretes to North America before rotating $67^{\circ}$ into its present-day orientation (Wells et al., 2014). This accretion is contemporaneous with the consumption of the last remnants of trapped Panthalassan crust on the Orcas plate, which is recorded by synchronous near-trench magmatism in southern Alaska and coastal British Columbia dated to $50 \mathrm{Ma}$ (Haeussler et al., 2003). North America reaches the Cascadia Root subduction zones (CR1, CR2) around the same time (55-50 Ma), according to tomotectonic reconstruction (Sigloch \& Mihalynuk, 2013). This timing matches the initiation of the present-day, Andean-style Cascadia arc on the margin of the northwestern United States (Schmandt \& Humphreys, 2011).

South of Insular and Intermontane superterranes, affiliated terranes that were left behind during the northward translation of Baja BC also accreted in the Eocene. The Western Jurassic belt reaches its present-day position alongside the native Jurassic arcs and the Sierra Nevada Batholith around 50 Ma. The Blue Mountains complete their 1,200 $\pm 460 \mathrm{~km}$ northward translation and $\sim 21^{\circ}$ clockwise rotation by $50 \mathrm{Ma}$, before rotating by $16^{\circ}$ into their current orientation between 45 and $35 \mathrm{Ma}$ (Housen \& Dorsey, 2005).

At $47 \mathrm{Ma}$, the Kronotsky arc shuts down, representing the end of intraoceanic subduction in the northeast Pacific (Figure 10). Cessation of subduction along this arc and the resulting change in plate driving forces could play a role in the formation of the enigmatic bend in the Hawaiian-Emperor chain that lies just to the south (Domeier et al., 2017). Following this shutdown, we fuse Olutorsky and Kronotsky to the Pacific plate, and they start to move northwest towards Kamchatka.

Mexico completes its anticlockwise rotation with respect to North America during the Eocene (UrrutiaFucugauchi, 1984). After this, the Chortis block shears into place as North America continues its westward drift (Seton et al., 2012).

For the Late Cenozoic, we make no changes to the continuously closing plate polygons of Müller et al. (2019). At $30 \mathrm{Ma}$ (Figure 10), the first contact between the Pacific and North American plates occurs in an eastward-protruding segment of the Pacific plate, located south of the Mendocino Fracture Zone, where the last remnants of the Farallon plate have subducted. This marks the oldest limit of the San Andreas Fault system, although most of the transform motion is thought to have occurred since the Miocene (Atwater, 1970).

Figure 11 details terrane motions along this segment of the margin, shown at 15, 10, 5, and 0 Ma. We implemented these motions following the model of McQuarrie and Wernicke (2005), which details the Neogene tectonic history. However, our model shows this motion on a coarser scale, illustrated using larger terranes, as opposed to the small blocks of McQuarrie and Wernicke (2005) or distributed deformation of Müller et al. (2019). One terrane that interacts with the San Andreas Fault is the Transverse Ranges block. It creates an east-west trending kink in the Californian coastline where the block crosscuts wider structures that are oriented northwest-southeast. Paleomagnetic studies show that the Transverse Ranges have experienced up to $100^{\circ}$ of clockwise rotation during the Neogene (Hornafius et al., 1986). Initial Transverse Ranges rotation is due to interaction between the Pacific and North American plates, final rotation driven by the opening of the Gulf of California since 6 Ma (McQuarrie \& Wernicke, 2005).

\section{Discussion}

We have presented a quantitative plate reconstruction with continuously closing plate boundaries for the eastern Pacific basin from $170 \mathrm{Ma}$ to present. It gives a more complete tectonic history for this region compared with the latest global models (e.g., Müller et al., 2019; see comparison, Figure 12). In contrast to a 

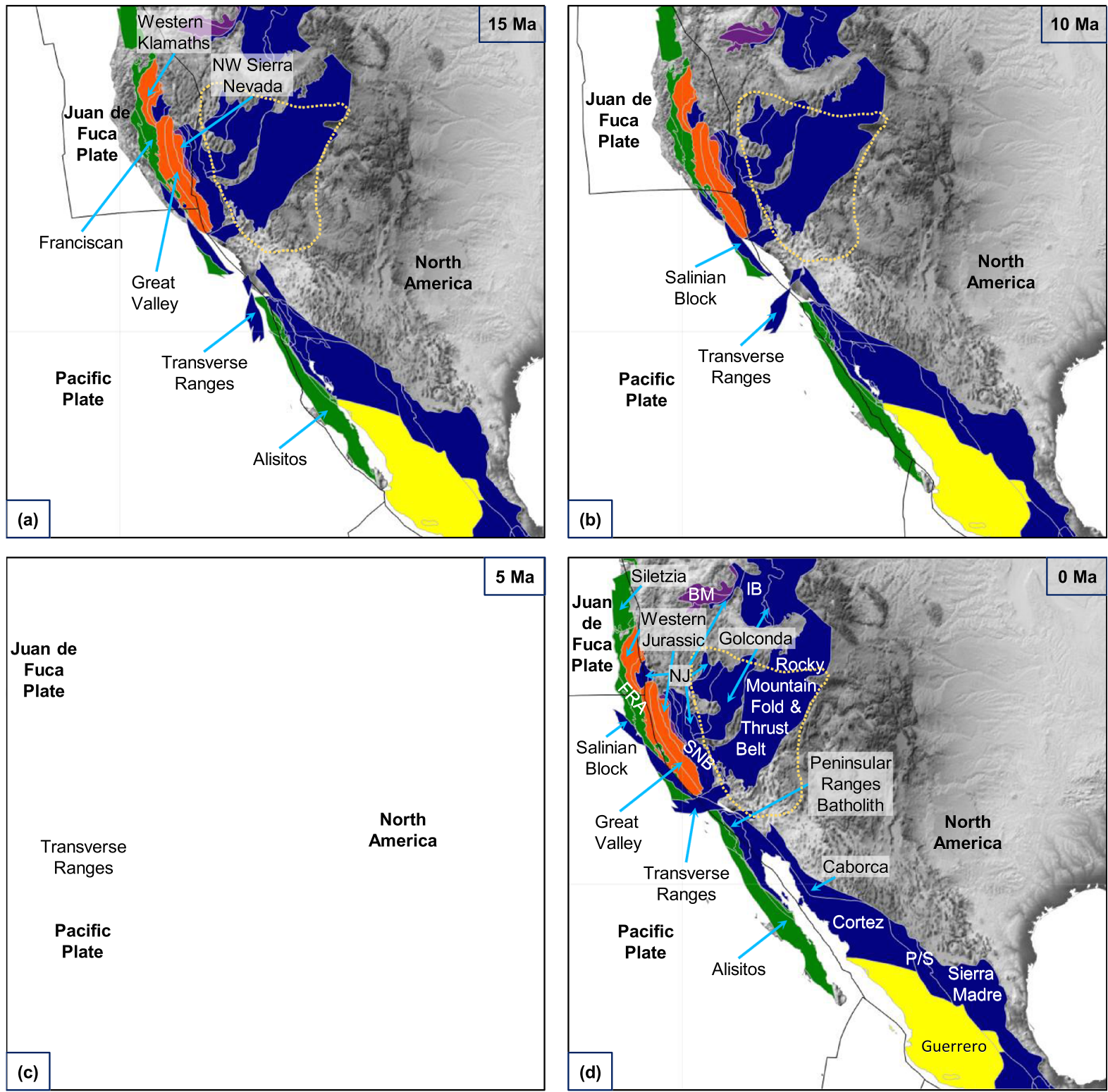

Figure 11. Terrane motions in the southwestern United States since $15 \mathrm{Ma}$, in $5 \mathrm{Myr}$ intervals. The terranes, labeled in (d), are implemented to move independently, following the model of McQuarrie and Wernicke (2005). The approximate extent of the Basin and Range province in western United States is outlined in gold. (a) $15 \mathrm{Ma}$ : prior to Basin and Range extension, terranes of the United States are located farther east than present day, for example, the green polygons of the Franciscan complex, alongside the Western Jurassic belt of Western Klamath, Great Valley, and NW Sierra Nevada, that do not reach the western coast of the basemap. The Transverse Ranges block is oriented northwest-southeast and is located outboard of Alisitos. (b) 10 Ma: The Salinian block continues to move northward on the Pacific plate side of the San Andreas Fault. The Transverse Ranges block now straddles the San Andreas Fault, which causes it to rotate clockwise. (c) $5 \mathrm{Ma}$ : early stage opening of the Gulf of California is linked to the northward motion of the Transverse Ranges block, which continues to rotate. (d) Present-day position of terranes. BM, Blue Mountains; IB, Idaho Batholith; NJ, Native Jurassic arc; SNB, Sierra Nevada Batholith; P/S, Parral/ Sombrerete.

170 Myr geologic history dominated by two plates-Farallon and North America-we present up to six oceanic plates between these two major plates. Although no in situ ocean floor for these plates survives at the surface, we can infer their existence by mapping subducted slabs in the mantle using seismic tomography. This paleoseafloor is arranged in highly informative geometries, localized vertically beneath the absolute trench locations where it entered the mantle (Sigloch \& Mihalynuk, 2013, 2017; van der Meer et al., 2010), directly tracing out the convergent paleoplate boundaries that have remained so elusive to plate reconstructions. 

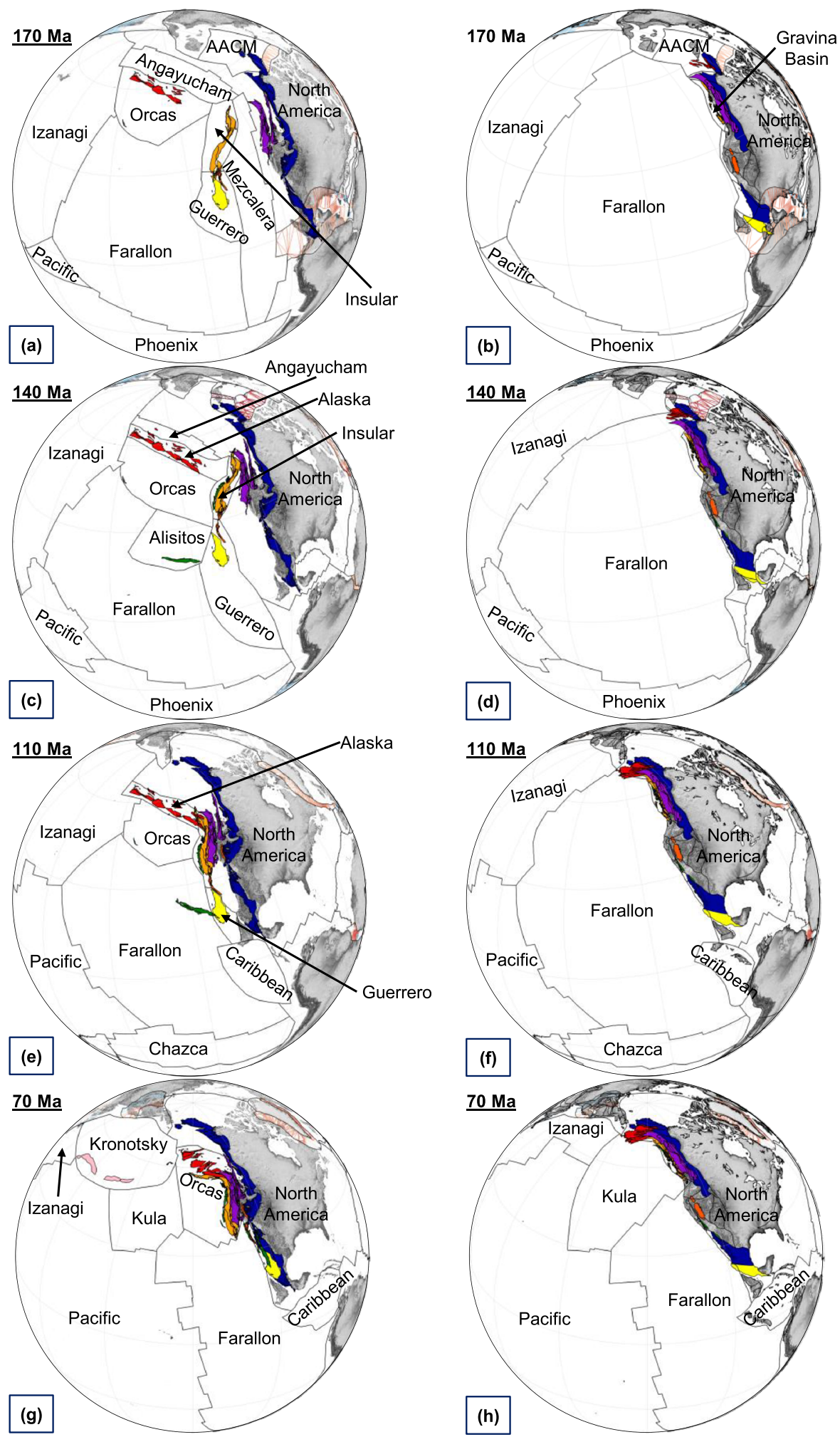

(g)

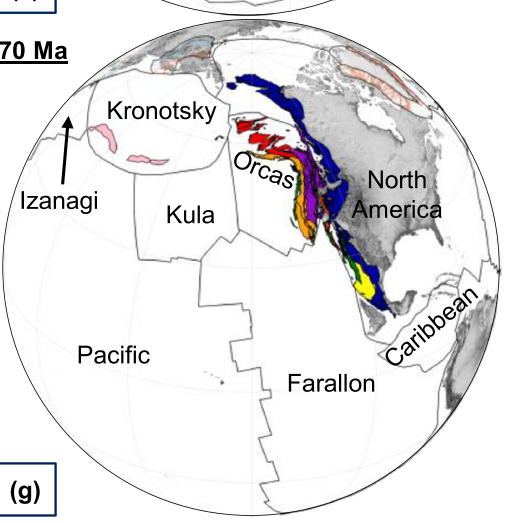

Figure 12. FigureComparison between our reconstruction (left column) and the model of Müller et al. (2019) (right column) at selected time steps. (a-f) Centered at $25^{\circ} \mathrm{N}$ and $90^{\circ} \mathrm{W}$. (g and $\mathrm{h}$ ) Centered on $30^{\circ} \mathrm{N}$ and $120^{\circ} \mathrm{W}$. Our model features more intraoceanic plates in place of the singular western Farallon plate in the Müller et al. (2019) model. Strung along these microplates' subduction zones are substantial chains of island arcs or even microcontinents. In the Müller et al. (2019) model, the same arcs have grown along the Andean-style margin of North America. These include the arcs of central Alaska (red), the Guerrero microcontinent (yellow), and the Insular microcontinent (orange). Our model also implements thousands of kilometers of margin-parallel (mostly northward) shuffling of terranes during and after accretion, unlike the Müller et al. (2019) model. 

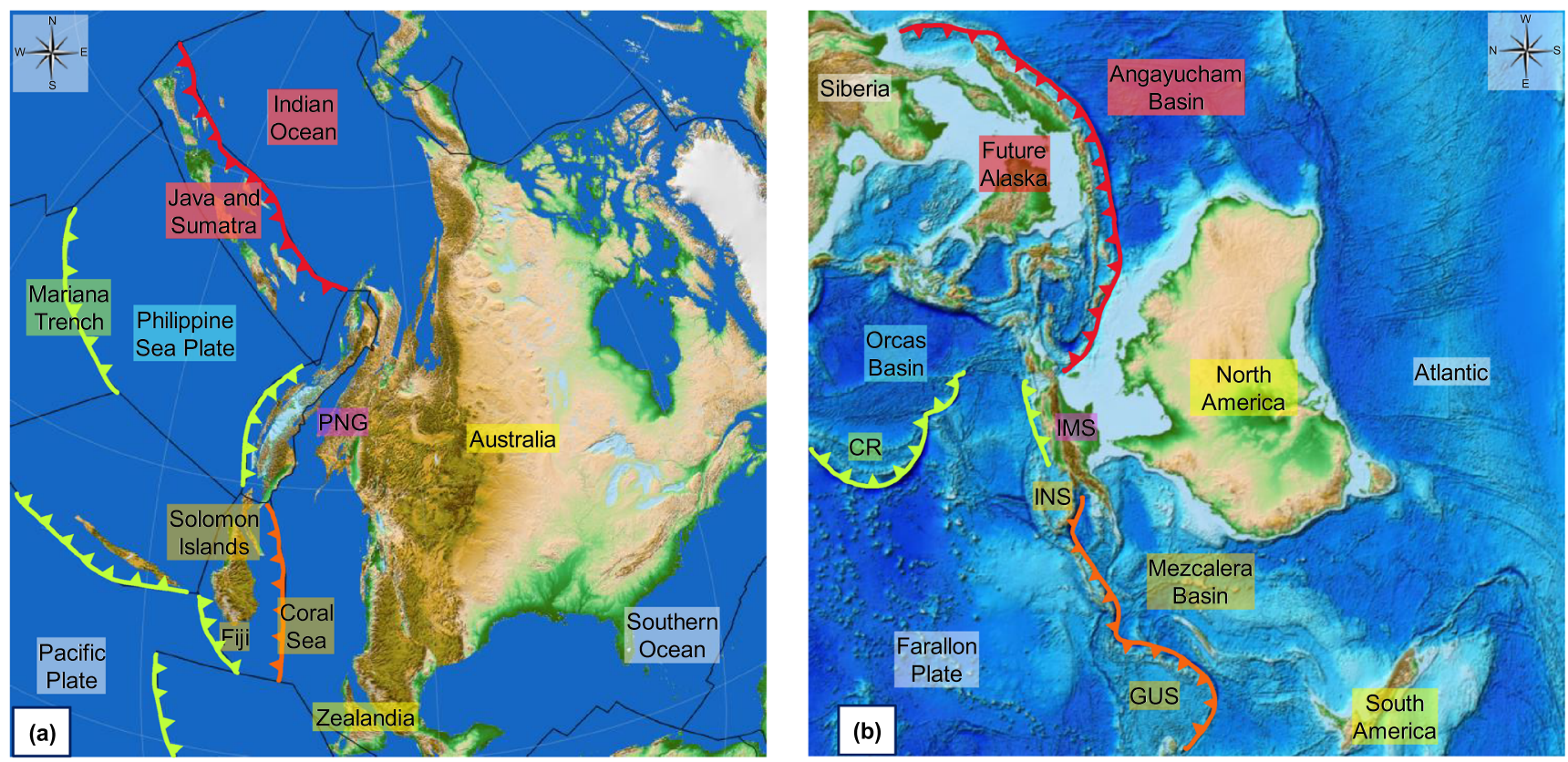

Figure 13. (a) North American reconstruction at $125 \mathrm{Ma}$, labeled with the names of its analogous elements in today's southwest Pacific. (b) Present-day southwest Pacific, labeled with the names of its analogous elements in the Cordilleran archipelago (after Sigloch and Mihalynuk, 2017). Australia was rotated anticlockwise by $90^{\circ}$ and mirrored vertically. The topologies of subduction zones are very similar, as are the resulting geological processes. The two continents were/are pulled into a vast red-orange line of arcs, which was previously unbroken but is starting to be accreted (Insular [INS] arc then versus northern Papua New Guinea [PNG] today), forcing a flip of subduction (to light green). A second, major oceanic domain is subducting from the opposite side (light green trenches: Farallon Ocean then versus Pacific Ocean today).

By associating the records of arc magmatism in the North American Cordillera with our inferred subduction zones, we reconstruct the absolute Jurassic-Cretaceous positions of two intraoceanic microcontinents- the Insular superterrane of British Columbia and southern Alaska and the Guerrero superterrane of western Mexico-as well as the massive chain of island arcs that would become central Alaska (Figure 12, left column). Existing quantitative reconstructions lumped all of these terranes with continental North America at all times (Figure 12, right column). The plate geometries and accretion sequences implied by the subducted slabs are successfully reconciled with the geological land record of the Cordillera, and they shed new light on the variable styles of terrane interactions with the continental margin through time and space.

Although our model is complex, it is no more complicated than plate interactions occurring today in the southwest Pacific and is in fact strikingly analogous, as shown in Figure 13. In this analogy, two major oceanic domains subduct beneath a vast archipelago from opposite sides-the Mezcalera and Angayucham oceans versus the Farallon Ocean, or the Indian Ocean and Coral Sea versus the Pacific Ocean. In either case, a major continent (Mesozoic North America or present-day Australia) is pulled into the archipelago from the non-Pacific side and starts to override its arcs (Mezcalera and Angayucham arcs, or Sunda and Coral Sea arcs). At present, Australia is diachronously colliding with New Guinea, causing the subduction polarity to flip from archipelago-ward to continent-ward. The detailed comparison in Figure 13 shows how arc geometries and collision processes of the Cretaceous western North America closely match those of today's southwest Pacific. It is likely that, in the geological future, the margin of Australia will be composed of suspect terranes, resembling the North American Cordillera (van Staal et al., 1998). Bird (2003) outlined 23 plates along the modern Australia and Pacific plate boundary-comparable with the level of complexity in our model. If one were to imagine attempting to reconstruct the southwest Pacific in the geological future, the challenges associated with interpreting mantle and geological data from overridden archipelagos become apparent.

One way of comparing plate reconstructions is to consider the trajectories of points of interest. In their groundbreaking reconstruction effort of the northeast Pacific basin, Engebretson et al. (1985) presented 


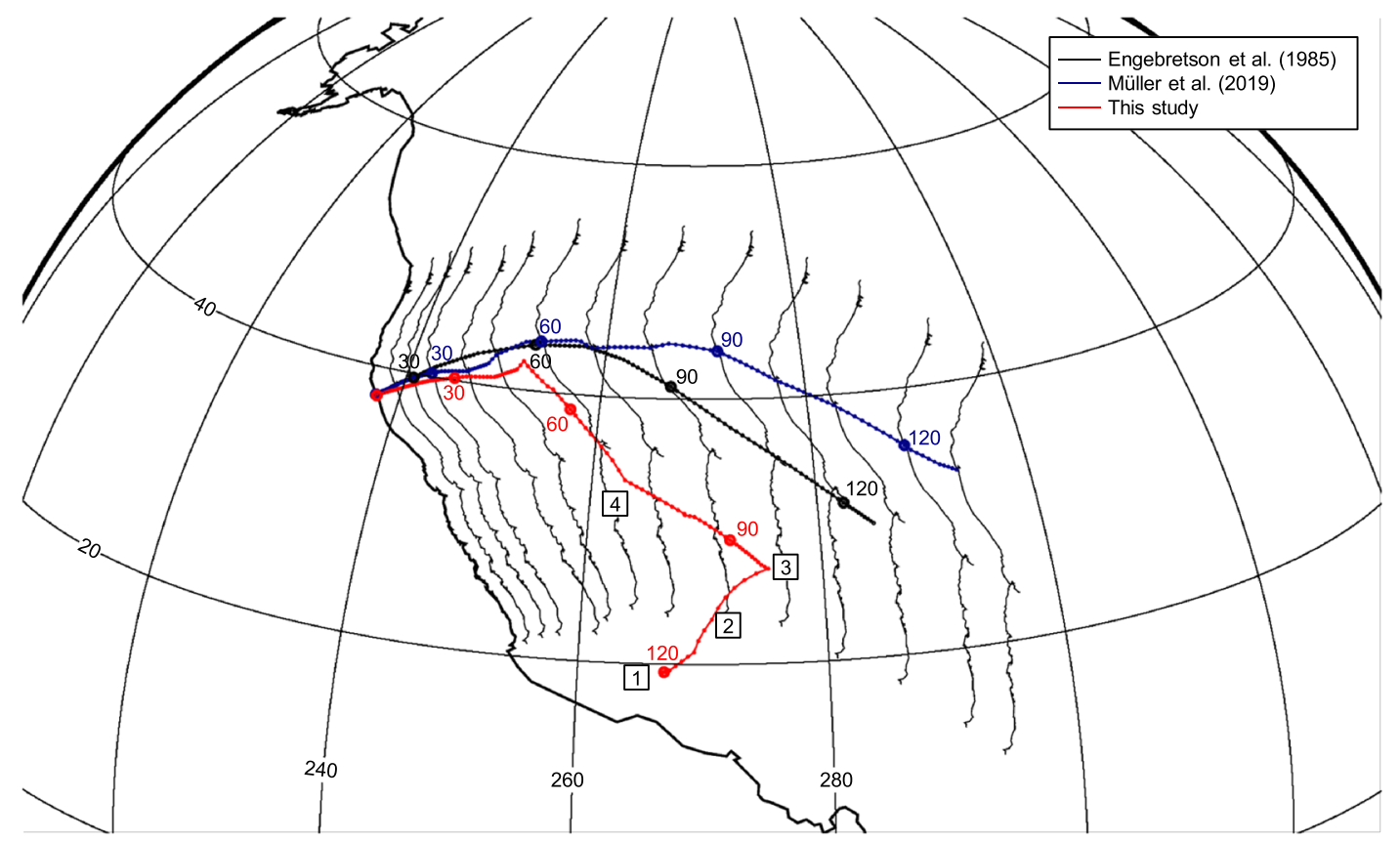

Figure 14. Trajectory of the city of San Francisco relative to the lower mantle, according to different plate reconstructions: Engebretson et al. (1985) (black), Müller et al. (2019) (blue), and this study (red). Small dots show the position of San Francisco at 1 Myr intervals, and large dots are every 30 Ma. The reconstructed U.S. coastline is plotted at intervals of 10 Myr. Previous reconstructions (black, blue) assumed that the Franciscan subduction complex was always located in the forearc of continuous Farallon subduction beneath the continental margin. This study infers a different, four-stage evolution of the Franciscan complex: (1) stationary along the intraoceanic Alisitos trench, with subduction of the Farallon plate beneath it; (2) transfer to the Farallon plate, moving northeastward; (3) accretion to the Western Jurassic Belt and continued growth in this continent-hugging Farallon trench; and (4) northward translation to present-day latitude.

the reconstructed trajectory of a point near San Francisco in order to highlight large displacements of the westward-drifting continent relative to the mantle. Figure 14 shows the journey of the city of San Francisco over geologic time in the model of Engebretson et al. (1985) and its similar trajectory in a more recent reconstruction of perennial Farallon-beneath-continent subduction (Müller et al., 2019). Both models show westward drift of an unchanging continental margin.

San Francisco sits atop an accretionary wedge, the Franciscan subduction complex, formed as slivers of incoming seafloor that were scraped off the subducting lithosphere to underplate the continental margin. A singular trajectory could not be applied to the various, unknowable locations where these offscrapings originally formed. Instead, these trajectories refer to the location of the accretionary process over time, which conventional reconstructions would identify with the perennial Farallon trench offshore San Francisco (black and blue paths of Figure 14).

Tracking the location of offscraping in our archipelago reconstruction yields a completely different journey for San Francisco that differs in both character and absolute path (red in Figure 14). The Franciscan terrane starts accumulating in the Early Cretaceous hanging wall of the intraoceanic Alisitos trench, far to the west of the North American coastline. This placement honors paleomagnetically determined latitudes of Franciscan rocks that were $\sim 1,000 \mathrm{~km}$ further south (Tarduno et al., 1985) of their paleoposition assigned by the reconstruction of Engebretson et al. (1985). Furthermore, the slab images indicate that subduction beneath the continental margin at this time is limited to a more northerly location, corresponding to present-day British Columbia. No compatible location exists for growth of the early Franciscan behind a continent-hugging trench.

By contrast, the intraoceanic, east-west striking ALI slab (Figure 6) has the correct southerly location, and its evolution will correctly send the early Franciscan towards its final destination. When the Alisitos trench shuts down $115 \mathrm{Ma}$ (section 3.3 and Figure 7), the now unanchored Franciscan terrane travels northeastward on the Farallon plate, which subducts beneath Guerrero superterrane. Franciscan rocks are then 
accreted to the Western Klamaths and Great Valley blocks, where the subduction complex continues to grow behind the continental Farallon trench. Its partial coupling to the obliquely subducting Farallon plate subsequently drives the Franciscan complex northward along the continental margin (Tarduno et al., 1985; compare Figure 8a with Figure 9a) to the site atop which San Francisco stands.

Our archipelago model reconciles geological and geophysical data where previous models have difficulties. Along the margin, locations on Insular superterrane (e.g., Vancouver Island) or on Guerrero (e.g., Guadalajara) would record significantly different trajectories to those predicted by Engebretson et al. (1985) and Müller et al. (2019). Differences for central Alaskan locations would show even greater contrast, especially for western Angayucham terranes which experience little absolute motion over the past 170 Myr, versus conventional models that predict a long, monotonous westward sweep at the margin of North America.

\section{Conclusion}

Our plate model illustrates the nature of intraoceanic subduction in the eastern proto-Pacific over the past 170 Myr, with plate boundaries evolving through time at a resolution of 1 Myr. Proposed plates, which are related to accreted microcontinents and arcs in the North American Cordillera, are constrained in their paleopositions by subduction zones derived from subducted slabs. Our inferred plates have reasonable geometries that follow established rules of plate tectonics and are consistent with a well-constrained global plate circuit. These plates-Angayucham, Mezcalera, Orcas, Insular, Guerrero, Alisitos, and Alaska—characterize intraoceanic subduction, diachronous archipelago override, and subsequent terrane accretion to western North America and are necessary to reconcile the available geological and geophysical data sets.

The self-consistent nature of this tomotectonic reconstruction highlights the importance of integrating surface and subsurface data into plate reconstructions. By combining seismically imaged slabs with evidence from geology, we have built a new tectonic model which provides an improved context for future interpretations of geological observations. With the potential to further constrain paleogeographic reconstructions in other areas of the globe, particularly in the Arctic and Caribbean regions which link into our model, the tomotectonic method can be a powerful tool in future studies.

\section{Data Availability Statement}

The digital plate reconstruction and associated data can be downloaded at https://www.earthbyte.org/webdav/ftp/Data_Collections/Clennett_etal_2020_G3/. All the tomography models used in this study (Sigloch_NAm_2011, DETOX-P1 and DETOX-P3) can be accessed and interactively visualized via the SubMachine web portal (http://submachine.earth.ox.ac.uk/).

\section{Conflict of Interest}

\section{Acknowledgments}

This project has received funding from the European Research Council (ERC) under the European Union's Horizon 2020 research and innovation program (grant agreement 639003 "DEEP TIME”). E.C. acknowledges additional support from the Burdett-Coutts fund, awarded by the Department of Earth Sciences, University of Oxford. K.S. acknowledges additional funding from a Philip Leverhulme Prize awarded by The Leverhulme Trust. M.S. and R.D. M. acknowledge support from the Australian Research Council through grants DP200100966 and IH130200012, respectively. S.T.J. was funded by an NSERC Discovery Grant. We thank Gene Humphreys and Jonny Wu for detailed and constructive reviews.
The authors declare no real or perceived conflict of interests.

\section{References}

Alvarez, W., Kent, D. V., Premoli Silva, I., Schweickert, R. A., \& Larson, R. A. (1980). Franciscan complex limestone deposited at $17^{\circ}$ south paleolatitude. Geological Society of America Bulletin, 91, 476-484. https://doi.org/10.1130/0016-7606(1980)91<476:FCLDAS>2.0.CO;2 Amaru, M. L. (2007). Global travel time tomography with 3-D reference models. Geologica Ultraiectina (Dissertation, Vol. 274). Utrecht University.

Amato, J. M., \& Pavlis, T. L. (2010). Detrital zircon ages from the Chugach terrane, southern Alaska, reveal multiple episodes of accretion and erosion in a subduction complex. Geology, 38(5), 459-462. https://doi.org/10.1130/G30719.1

Atwater, T. (1970). Implications of plate tectonics for the Cenozoic tectonic evolution of western North America. GSA Bulletin, 81(12), 3513-3536. https://doi.org/10.1130/0016-7606(1970)81[3513:IOPTFT]2.0.CO;2

Atwater, T. (1989). Plate tectonic history of the northeast Pacific and western North America. In E. L. Winterer, D. M. Hussong, \& R. W. Decker (Eds.), The Eastern Pacific Ocean and Hawaii, The Geology of North America (Vol. N, pp. 21-72). Boulder, CO: Geological Society of America.

Bird, P. (2003). An updated digital model of plate boundaries. Geochemistry Geophysics Geosystems, 4(3), 1027. https://doi.org/10.1029/ 2001GC000252

Butterworth, N. P., Talsma, A. S., Müller, R. D., Seton, M., Bunge, H. -P., Schuberth, B. S. A., et al. (2014). Geological, tomographic, kinematic and geodynamic constraints on the dynamics of sinking slabs. Journal of Geodynamics, 73, 1-13. https://doi.org/10.1016/j. jog.2013.10.006 
Colpron, M., \& Nelson, J. L. (2011). A digital atlas of terranes for the Northern Cordillera. BCGS GeoFile, 2011-11.

Coney, P. J., Jones, D. L., \& Monger, J. W. (1980). Cordilleran suspect terranes. Nature, 288, 329-333. https://doi.org/10.1038/288329a0

DeCelles, P. G. (2004). Late Jurassic to Eocene evolution of the Cordilleran thrust belt and foreland basin system, western U.S.A. American Journal of Science, 304, 105-168. https://doi.org/10.2475/ajs.304.2.105

DeCelles, P. G., \& Coogan, J. C. (2006). Regional structure and kinematic history of the Sevier fold-and-thrust belt, central Utah. Geological Society of America Bulletin, 118(7-8), 841-864. https://doi.org/10.1130/B25759.1

Dickinson, W. R. (2004). Evolution of the North American Cordillera. Annual Review of Earth and Planetary Sciences, 32, 13-45. https://doi. org/10.1146/annurev.earth.32.101802.120257

Dickinson, W. R. (2008). Accretionary Mesozoic-Cenozoic expansion of the Cordilleran continental margin in California and adjacent Oregon. Geosphere, 4, 329-353. https://doi.org/10.1130/GES00105.1

Dickinson, W. R., \& Lawton, T. F. (2001). Carboniferous to Cretaceous assembly and fragmentation of Mexico. GSA Bulletin, 113(9), 1142-1160. https://doi.org/10.1130/0016-7606(2001)113<1142:CTCAAF > 2.0.CO;2

Domeier, M., Shephard, G. E., Jakob, G. E., Gaina, C., Doubrovine, P. V., \& Torsvik, T. H. (2017). Intraoceanic subduction spanned the Pacific in the Late Cretaceous-Paleocene. Science Advances, 3(11), eaao2303. https://doi.org/10.1126/sciadv.aao2303

Doubrovine, P. V., Steinberger, B., \& Torsvik, T. H. (2012). Absolute plate motions in a reference frame defined by moving hot spots in the Pacific, Atlantic and Indian oceans. Journal Geophysical Research, 117, B09101. https://doi.org/10.1029/2011JB009072

Ducea, M. (2001). The California arc: Thick granitic batsholiths, eclogitic residues, lithospheric-scale thrusting, and magmatic flare-ups. GSA Today, 11, 4-10. https://doi.org/10.1130/1052-5173(2001)011<0004:TCATGB >2.0.CO;2

Dumitru, T. A., Wakabayashi, J., Wright, J. E., \& Wooden, J. L. (2010). Early Cretaceous transition from nonaccretionary behavior to strongly accretionary behavior within the Franciscan subduction complex. Tectonics, 29, TC5001. https://doi.org/10.1029/ 2009TC002542

Engebretson, D. C., Cox, A., \& Gordon, R. G. (1985). Relative motions between oceanic and continental plates in the Pacific basin. Geological Society of America. Special Paper, 206. https://doi.org/10.1130/SPE206-p1

Enkin, R. J. (2006). Paleomagnetism and the case for Baja-British Columbia: Paleogeography of the North American Cordillera. In J. Haggart, R. J. Enkin, \& J. W. H. Monger (Eds.), Paleogeography of the North American Cordillera: Evidence for and against large-scale displacements, Geological Association of Canada Special Paper (Vol. 46, pp. 233-253).

Forsyth, D., \& Uyeda, S. (1975). On the relative importance of the driving forces of plate motion. Geophysical Journal of the Royal Astronomical Society, 43, 163-200. https://doi.org/10.1111/j.1365-246X.1975.tb00631.x

Garver, J. I., \& Davidson, C. M. (2015). Southwestern Laurentian zircons in Upper Cretaceous flysch of the Chugach-Prince William Terrane in Alaska. American Journal of Science, 315, 537-556. https://doi.org/10.2475/06.2015.02

Grand, S. P. (1994). Mantle shear structure beneath the Americas and surrounding oceans. Journal of Geophysical Research, 99(B6), 11,591-11,621. https://doi.org/10.1029/94JB00042

Grove, M., Bebout, G. E., Jacobson, C. E., Barth, A. P., Kimbrough, D. L., King, R. L., et al. (2008). The Catalina Schist: Evidence for middle Cretaceous subduction erosion of southwestern North America. In A. E. Draut, P. D. Clift, \& D. W. Scholl, (Eds.) Formation and applications of the sedimentary record in arc collision zones. Geological Society of America Special Paper (Vol. 436, pp. 335-361). Boulder, CO: Geological Society of America. https://doi.org/10.1130/2008.2436(15)

Gurnis, M., Turner, M., Zahirovic, S., DiCaprio, L., Spasojevic, S., Müller, R. D., et al. (2012). Plate tectonic reconstructions with continuously closing plates. Computers \& Geosciences, 38(1), 35-42. https://doi.org/10.1016/j.cageo.2011.04.014

Haeussler, P. J., Bradley, D. C., Wells, R. E., \& Miller, M. L. (2003). Life and death of the Resurrection plate: Evidence for its existence and subduction in the northeastern Pacific in Paleocene-Eocene time. GSA Bulletin, 115(7), 867-880. https://doi.org/10.1130/00167606(2003)115<0867:LADOTR>2.0.CO;2

Harper, G. D., Saleeby, J. B., \& Heizler, M. (1994). Formation and emplacement of the Josephine ophiolite and the Nevadan orogeny in the Klamath Mountains, California-Oregon: U/Pb zircon and ${ }^{40} \mathrm{Ar} /{ }^{39} \mathrm{Ar}$ geochronology. Journal of Geophysical Research, 99(B3), 4293-4321. https://doi.org/10.1029/93JB02061

Hornafius, J. S., Luyendyk, B. P., Terres, R. R., \& Kamerling, M. J. (1986). Timing and extent of Neogene tectonic rotation in the western Transverse Ranges, California. GSA Bulletin, 97(12), 1476-1487. https://doi.org/10.1130/0016-7606(1986)97<1476: TAEONT > 2.0.CO;2

Hosseini, K., Matthews, K. J., Sigloch, K., Shephard, G. E., Domeier, M., \& Tsekhmistrenko, M. (2018). SubMachine: Web-based tools for exploring seismic tomography and other models of Earth's deep interior. Geochemistry, Geophysics, Geosystems, 19, 1464-1483. https:// doi.org/10.1029/2018GC007431

Hosseini, K., \& Sigloch, K. (2015). Multifrequency measurements of core-diffracted $P$ waves (Pdiff) for global waveform tomography. Geophysical Journal International, 203(1), 506-521. https://doi.org/10.1093/gji/ggv298

Hosseini, K., Sigloch, K., Tsekhmistrenko, M., Zaheri, A., Nissen-Meyer, T., \& Igel, H. (2020). Global mantle structure from multi-frequency tomography using P, PP and P-diffracted waves. Geophysical Journal International, 220(1), 96-141. https://doi.org/ 10.1093/gji/ggz394

Housen, B. A., \& Dorsey, R. J. (2005). Paleomagnetism and tectonic significance of Albian and Cenomanian turbidites, Ochoco Basin, Mitchell Inlier, central Oregon. Journal of Geophysical Research, 110, B07102. https://doi.org/10.1029/2004JB003458

Humphreys, E., Hessler, E., Dueker, K., Farmer, G. L., Erslev, E., \& Atwater, T. (2003). How Laramide-age hydration of North American lithosphere by the Farallon slab controlled subsequent activity in the western United States. International Geology Review, 45(7), 575-595. https://doi.org/10.2747/0020-6814.45.7.575

Ingersoll, R. V. (2008). Subduction-related sedimentary basins of the USA Cordillera. In A. D. Miall (Ed.) Sedimentary basins of the world, Amsterdam (Vol. 5, pp. 395-428). Netherlands: Elsevier. https://doi.org/10.1016/S1874-5997(08)00011-7

Ingersoll, R. V., \& Schweickert, R. A. (1986). A plate-tectonic model for Late Jurassic ophiolite genesis, Nevadan orogeny and forearc initiation, northern California. Tectonics, 5(6), 901-912. https://doi.org/10.1029/TC005i006p00901

Irving, E. (1985). Whence British Columbia. Nature, 314, 673-674. https://doi.org/10.1038/314673a0

Irving, E., \& Wynne, P. J. (1991). Paleomagnetic evidence for motions of parts of the Canadian Cordillera. Tectonophysics, 187(1-3), 259-275. https://doi.org/10.1016/0040-1951(91)90423-P

Johnson, S. E., Tate, M. C., \& Fanning, C. M. (1999). New geologic mapping and SHRIMP U-Pb zircon data in the Peninsular Ranges batholith, Baja California, Mexico: Evidence for a suture? Geology, 27(8), 743-746. https://doi.org/10.1130/0091-7613(1999)027<0743: NGMASU $>2.3 . \mathrm{CO} ; 2$

Johnston, S. T. (2001). The Great Alaskan terrane wreck: Reconciliation of paleomagnetic and geological data in the northern Cordillera Earth and Planetary Science Letters, 193, 259-272. https://doi.org/10.1016/S0012-821X(01)00516-7 
Kent, D. V., \& Irving, E. (2010). Influence of inclination error in sedimentary rocks on the Triassic and Jurassic apparent pole wander path for North America and implications for Cordilleran tectonics. Journal of Geophysical Research, 115, B10103. https://doi.org/10.1029/ 2009JB007205

LaMaskin, T. A., Dorsey, R. J., Vervoort, J. D., Schmitz, M. D., Tumpane, K. P., \& Moore, N. O. (2015). Westward growth of Laurentia by Pre-Late Jurassic terrane accretion, Eastern Oregon and Western Idaho, United States. The Journal of Geology, 123(3), 233-267. https:// doi.org/10.1086/681724

Li, C., van der Hilst, R. D., Engdahl, E. R., \& Burdick, S. (2008). A new global model for $P$ wave speed variations in Earth's mantle. Geochemistry, Geophysics, Geosystems, 9, Q05018. https://doi.org/10.1029/2007GC001806

Livaccari, R. F., Burke, K., \& Şengör, A. M. C. (1981). Was the Laramide orogeny related to subduction of an oceanic plateau? Nature, 289, 276-278. https://doi.org/10.1038/289276a0

MacDonald, J. H. Jr., Harper, G. D., Miller, R. B., Miller, J. S., Mlinarevic, A. N., \& Schultz, C. E. (2008). The Ingalls ophiolite complex, central Cascades, Washington: Geochemistry, tectonic setting, and regional correlations. In J. E. Wright \& J. W. Shervais (Eds.), Ophiolites, arcs, and batholiths: A tribute to Cliff Hopson, Geological Society of America Special Paper (Vol. 438, pp. 133-159). Boulder, CO: Geological Society of America. https://doi.org/10.1130/2008.2438(04)

McClelland, W. C., Gehrels, G. E., \& Saleeby, J. B. (1992). Upper Jurassic-Lower Cretaceous basinal strata along the Cordilleran margin: Implications for the accretionary history of the Alexander-Wrangellia-Peninsular terrane. Tectonics, 11(4), 823-835. https://doi.org/ $10.1029 / 92 \mathrm{TC} 00241$

McKenzie, D. P., \& Parker, R. L. (1967). The North Pacific: An example of tectonics on a sphere. Nature, 216, 1276-1280. https://doi.org/ $10.1038 / 2161276 \mathrm{a} 0$

McQuarrie, N., \& Wernicke, B. P. (2005). An animated tectonic reconstruction of southwestern North America since 36 Ma. Geosphere, 1(3), 147-172. https://doi.org/10.1130/GES00016.1

Mihalynuk, M. G., Erdmer, P., Ghent, E. D., Cordey, F., Archibald, D. A., Friedman, R. M., \& Johannson, G. G. (2004). Coherent French Range blueschist: Subduction to exhumation in <2.5 m.y.? GSA Bulletin, 116(7-8), 910-922. https://doi.org/10.1130/ B25393.1

Mihalynuk, M. G., Nelson, J., \& Diakow, L. J. (1994). Cache Creek terrane entrapment: Oroclinal paradox within the Canadian Cordillera. Tectonics, 13(3), 575-595. https://doi.org/10.1029/93TC03492

Miller, M. L., Bradley, D. C., Bundtzen, T. K., \& McClelland, W. (2002). Late Cretaceous through Cenozoic strike-slip tectonics of southwestern Alaska. The Journal of Geology, 110(3), 247-270. https://doi.org/10.1086/339531

Mohammadzaheri, A. (2019). Mantle structures under South America using multi-frequency tomography. United Kingdom: PhD thesis, University of Oxford.

Moores, E. (1970). Ultramafics and orogeny, with models of the US Cordillera and the Tethys. Nature, 228, 837-842. https://doi.org/ $10.1038 / 228837 \mathrm{a} 0$

Moores, E. (1998). Ophiolites, the Sierra Nevada, "Cordilleria," and orogeny along the Pacific and Caribbean margins of North and South America. International Geology Review, 40(1), 40-54. https://doi.org/10.1080/00206819809465197

Morgan, W. J. (1968). Rises, trenches, great faults, and crustal blocks. Journal of Geophysical Research, 73(6), 1959-1982. https://doi.org/ 10.1029/JB073i006p01959

Müller, R. D., Cannon, J., Qin, X., Watson, R. J., Gurnis, M., Williams, S., et al. (2018). GPlates: Building a virtual Earth through deep time. Geochemistry, Geophysics, Geosystems, 19, 2243-2261. https://doi.org/10.1029/2018GC007584

Müller, R. D., Royer, J. -Y., \& Lawver, L. A. (1993). Revised plate motions relative to the hotspots from combined Atlantic and Indian Ocean hotspot tracks. Geology, 21(3), 275-278. https://doi.org/10.1130/0091-7613(1993)021<0275:RPMRTT>2.3.CO;2

Müller, R. D., Zahirovic, S., Williams, S. E., Cannon, J., Seton, M., Bower, D. J., et al. (2019). A global plate model including lithospheric deformation along major rifts and orogens since the Triassic. Tectonics, 38, 1884-1907. https://doi.org/10.1029/ 2018TC005462

O'Neill, C., Müller, R. D., \& Steinberger, B. (2005). On the uncertainties in hotspot reconstructions, and the significance of moving hotspot reference frames. Geochemistry, Geophysics, Geosystems, 6, Q04003. https://doi.org/10.1029/2004GC000784

Sager, W., Handschumacher, D., Hilde, T., \& Bracey, D. (1988). Tectonic evolution of the northern Pacific plate and Pacific-FarallonIzanagi triple junction in the Late Jurassic and Early Cretaceous (M21-M10). Tectonophysics, 155, 345-364. https://doi.org/10.1016/ 0040-1951(88)90274-0

Schmandt, B., \& Humphreys, E. (2011). Seismically imaged relict slab from the 55 Ma Siletzia accretion to the northwest United States. Geology, 39(2), 175-178. https://doi.org/10.1130/G31558.1

Seton, M., Müller, R. D., Zahirovic, S., Gaina, C., Torsvik, T. H., Talsma, A. G., et al. (2012). Global continental and ocean basin reconstructions since 200 Ma. Earth-Science Reviews, 113(3-4), 212-270. https://doi.org/10.1016/j.earscirev.2012.03.002

Shephard, G. E., Bunge, H. -P., Schuberth, B. S. A., Müller, R. D., Talsma, A. S., Moder, C., \& Landgrebe, T. C. W. (2012). Testing absolute plate reference frames and the implications for the generation of geodynamic mantle heterogeneity structure. Earth and Planetary Science Letters, 317-318, 204-217. https://doi.org/10.1016/j.epsl.2011.11.027

Shephard, G. E., Matthews, K. J., Hosseini, K., \& Domeier, M. (2017). On the consistency of seismically imaged lower mantle slabs. Science Reports, 7(1), 10,976. https://doi.org/10.1038/s41598-017-11039-w

Shephard, G. E., Müller, R. D., \& Seton, M. (2013). The tectonic evolution of the Arctic since Pangea breakup: Integrating constraints from surface geology and geophysics with mantle structure. Earth-Science Reviews, 124, 148-183. https://doi.org/10.1016/j. earscirev.2013.05.012

Sigloch, K. (2011). Mantle provinces under North America from multifrequency P-wave tomography. Geochemistry, Geophysics, Geosystems, 12, Q02W08. https://doi.org/10.1029/2010GC003421

Sigloch, K., McQuarrie, N., \& Nolet, G. (2008). Two-stage subduction history under North America inferred from multiple-frequency tomography. Nature Geoscience, 1, 458-462. https://doi.org/10.1038/ngeo231

Sigloch, K., \& Mihalynuk, M. G. (2013). Intra-oceanic subduction shaped the assembly of Cordilleran North America. Nature, $496,50-56$. https://doi.org/10.1038/nature12019

Sigloch, K., \& Mihalynuk, M. G. (2017). Mantle and geological evidence for a Late Jurassic-Cretaceous suture spanning North America. GSA Bulletin, 129(11-12), 1489-1520. https://doi.org/10.1130/B31529.1

Silberling, N. J., Jones, D. L., Monger, J. W. H., \& Coney, P. J. (1992). Lithotectonic terrane map of the North American Cordillera. U.S. Geological Survey, Map I-2176. https://doi.org/10.3133/i2176

Steinberger, B., \& Torsvik, T. (2008). Absolute plate motions and true polar wander in the absence of hotspot tracks. Nature, 452, 620-623. https://doi.org/10.1038/nature06824 
Tarduno, J. A., McWillams, M., \& Sleep, N. (1990). Fast instantaneous oceanic plate velocities recorded by the Cretaceous Laytonville limestone: Paleomagnetic analysis and kinematic implications. Journal of Geophysical Research, 95, 15,503-15,527. https://doi.org/ 10.1029/JB095iB10p15503

Tarduno, J. A., McWilliams, M., Debiche, M. G., Sliter, W. V., \& Blake, M. C. (1985). Franciscan complex Calera limestones: Accreted remnants of Farallon plate oceanic plateaus. Nature, 317, 345-347. https://doi.org/10.1038/317345a0

Tetley, M. G., Williams, S. E., Gurnis, M., Flament, N., \& Müller, R. D. (2019). Constraining absolute plate motions since the Triassic. Journal of Geophysical Research: Solid Earth, 124, 7231-7258. https://doi.org/10.1029/2019JB017442

Torsvik, T. H., Müller, R. D., Van der Voo, R., Steinberger, B., \& Gaina, C. (2008). Global plate motion frames: Toward a unified model. Reviews of Geophysics, 46, RG3004. https://doi.org/10.1029/2007RG000227

Torsvik, T. H., Steinberger, B., Shephard, G. E., Doubrovine, P. V., Gaina, C., Domeier, M., et al. (2019). Pacific-Panthalassic reconstructions: Overview, errata and the way forward. Geochemistry, Geophysics, Geosystems, 20, 3659-3689. https://doi.org/10.1029/ 2019GC008402

Torsvik, T. H., Van der Voo, R., Preeden, U., Mac Niocaill, C., Steinberger, B., Doubrovine, P. V., et al. (2012). Phanerozoic polar wander, paleogeography and dynamics. Earth Science Reviews, 114(3-4), 325-368. https://doi.org/10.1016/j.earscirev.2012.06.007

Urrutia-Fucugauchi, J. (1981). Paleomagnetic evidence for tectonic rotation of northern Mexico and the continuity of the Cordilleran orogenic belt between Nevada and Chihuahua. Geology, 9(4), 178-183. https://doi.org/10.1130/0091-7613(1981)9<178:PEFTRO>2.0 $\mathrm{CO} ; 2$

Urrutia-Fucugauchi, J. (1984). On the tectonic evolution of Mexico: Paleomagnetic constraints. In R. van der Voo, C. Scotese, \& N. Bonhommet (Eds.), Plate reconstruction from Paleozoic paleomagnetism, Geodynamic Series (Vol. 12, pp. 29-47). Washington, DC: AGU. https://doi.org/10.1029/GD012p0029

Vaes, B., van Hinsbergen, D. J. J., \& Boschman, L. M. (2019). Reconstruction of subduction and back-arc spreading in the NW Pacific and Aleutian basin: Clues to causes of Cretaceous and Eocene plate reorganizations. Tectonics, 38, 1367-1413. https://doi.org/10.1029/ 2018TC005164

van der Meer, D. G., Spakman, W., van Hinsbergen, D. J. J., Amaru, M. L., \& Torsvik, T. H. (2010). Towards absolute plate motions constrained by lower-mantle slab remnants. Nature Geoscience, 3, 36-40. https://doi.org/10.1038/ngeo708

van Staal, C. R., Dewey, J. E., Mac Niocaill, C., \& McKerrow, W. S. (1998). The Cambrian-Silurian tectonic evolution of the northern Appalachians and British Caledonides: History of a complex, west and southwest Pacific-type segment of Iapetus. In D. J. Blundell \& A C. Scott (Eds.), Lyell: The past is the key to the present, Geological Society, London, Special Publications (Vol. 143, pp. 199-242). London: Geological Society of London. https://doi.org/10.1144/GSL.SP.1998.143.01.17

Wells, R., Bukry, D., Friedman, R., Pyle, D., Duncan, R., Haeussler, P., \& Wooden, J. (2014). Geologic history of Siletzia, a large igneous province in the Oregon and Washington Coast Range: Correlation to the geomagnetic polarity time scale and implications for a long-lived Yellowstone hotspot. Geosphere, 10(4), 692-719. https://doi.org/10.1130/GES01018.1

Wetmore, P. H., Hughes, S. S., Stremtan, C., Ducea, M. N., \& Alsleben, H. (2014). Tectonic implications of postcontractional magmatism of the Alisitos arc segment of the Peninsular Ranges, Baja California, Mexico. In D. M. Morton \& F. K. Miller (Eds.) Peninsular Ranges Batholith, Baja California and Southern California, Geological Society of America Memoir (Vol. 211, pp. 669-690). Boulder, CO: Geological Society of America. https://doi.org/10.1130/2014.1211(21)

Williams, S. E., Flament, N., Müller, R. D., \& Butterworth, N. (2015). Absolute plate motions since 130 Ma constrained by subduction zone kinematics. Earth and Planetary Science Letters, 418, 66-77. https://doi.org/10.1016/j.epsl.2015.02.026 